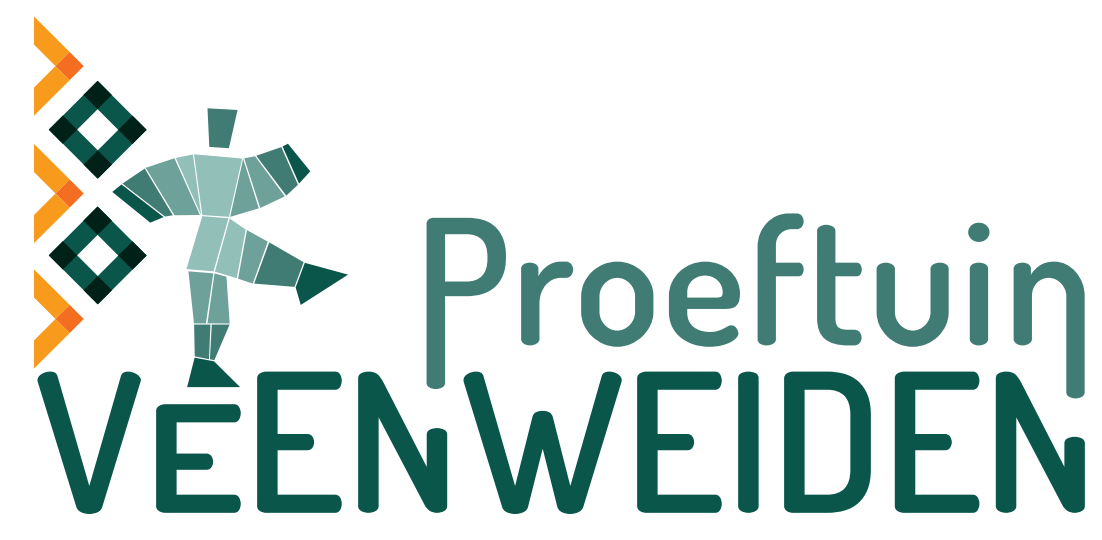

\title{
Borgen van maatregelen om ammoniakemissie
} te reduceren

Gerard Migchels, Leo Joosten, Marieke van Leeuwen, Reina Ferwerda, Wim Houwers

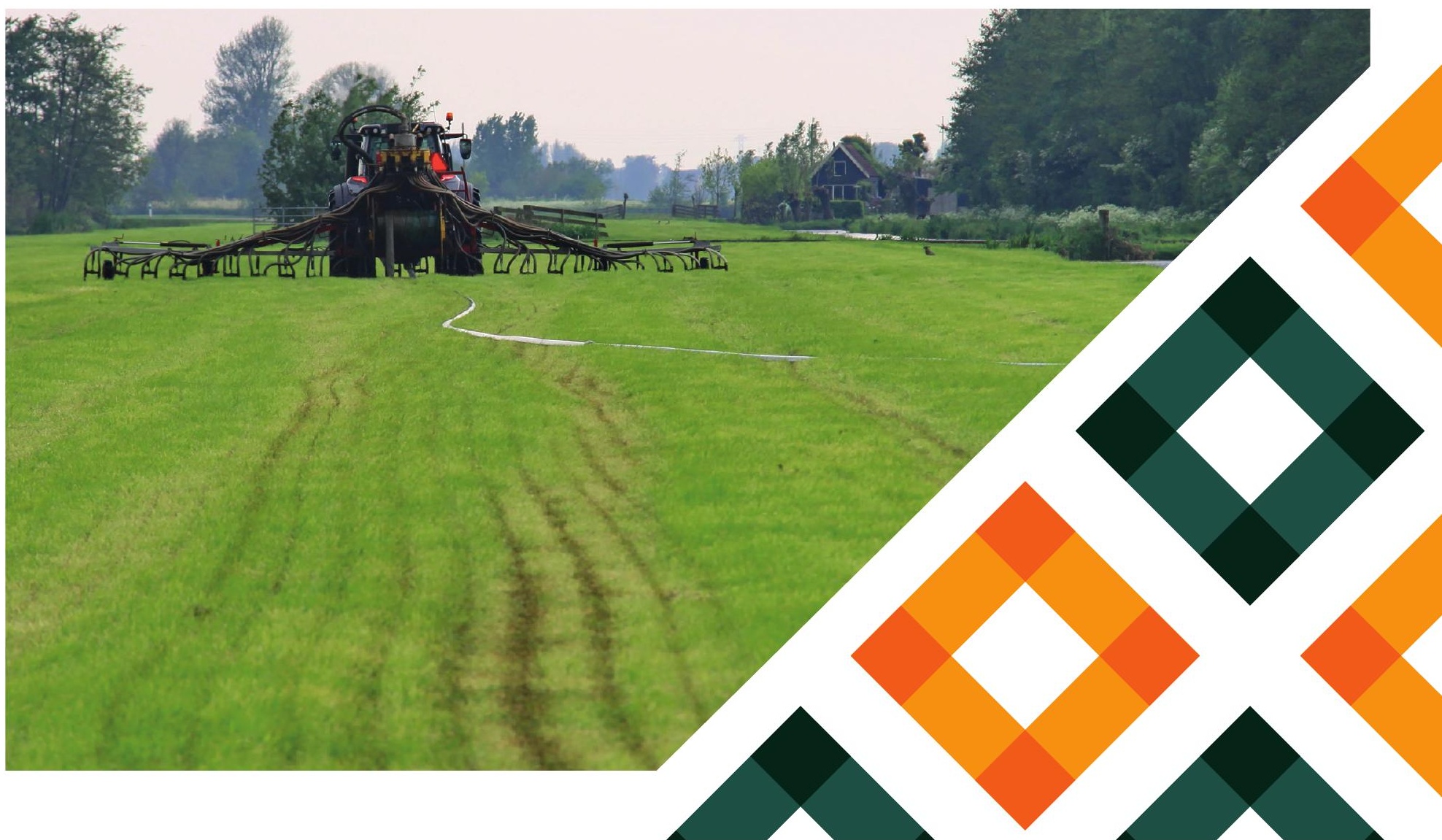





\title{
Borgen van maatregelen om ammoniakemissie te reduceren
}

Gerard Migchels $^{1}$, Leo Joosten ${ }^{2}$, Marieke van Leeuwen ${ }^{3}$, Reina Ferwerda ${ }^{1}$, Wim Houwers ${ }^{1}$

\author{
1 Wageningen Livestock Research \\ 2 ORG-ID \\ 3 Projecten LTO Noord
}

LTO Noord startte begin 2016 met het innovatieprogramma Proeftuin Veenweiden en wordt daarbij financieel ondersteund door provincie Zuid-Holland, het Ministerie van Economische Zaken, het Melkveefonds en het LTO Noord Fonds. De Proeftuin is een initiatief van LTO Noord en VIC Zegveld. De uitvoering van het programma is in handen van LTO Noord, Wageningen University \& Research, VIC Zegveld, PPP-Agro Advies, ORG-ID en het Louis Bolk Instituut.

Wageningen Livestock Research

Wageningen, augustus 2019

Rapport 1196 
Gerard Migchels, Leo Joosten, Marieke van Leeuwen, Reina Ferwerda, Wim Houwers, 2019. Borgen van maatregelen om ammoniakemissie te reduceren. Wageningen Livestock Research, Rapport 1196.

Dit rapport is gratis te downloaden op https://doi.org/10.18174/500787 of op www.wur.nl/livestock-research (onder Wageningen Livestock Research publicaties).

(c) 2019 Wageningen Livestock Research

Postbus 338, 6700 AH Wageningen, T 03174839 53, E info.livestockresearch@wur.nl, www.wur.nl/livestock-research. Wageningen Livestock Research is onderdeel van Wageningen University \& Research.

Wageningen Livestock Research aanvaardt geen aansprakelijkheid voor eventuele schade voortvloeiend uit het gebruik van de resultaten van dit onderzoek of de toepassing van de adviezen.

Alle rechten voorbehouden. Niets uit deze uitgave mag worden vermenigvuldigd en/of openbaar gemaakt worden door middel van druk, fotokopie, microfilm of op welke wijze dan ook zonder voorafgaande toestemming van de uitgever of auteur.

Wageningen Livestock Research is NEN-EN-ISO 9001:2015 gecertificeerd. Op al onze onderzoeksopdrachten zijn de Algemene Voorwaarden van de Animal Sciences Group van toepassing. Deze zijn gedeponeerd bij de Arrondissementsrechtbank Zwolle.

Wageningen Livestock Research Rapport 1196 


\section{Inhoud}

$\begin{array}{ll}\text { Samenvatting } & \mathbf{5}\end{array}$

$\begin{array}{lll}1 & \text { Inleiding } & 7\end{array}$

$\begin{array}{lll}1.1 & \text { Waarom borgen? } & 7\end{array}$

1.2 Om welke maatregelen gaat het? $\quad 8$

$\begin{array}{lll}1.3 & \text { Doelstelling } & 8\end{array}$

1.4 Leeswijzer $\quad 8$

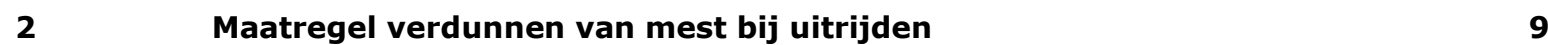

2.1 Aanleiding 9

2.2 Twee borgingssystemen vergeleken $\quad 9$

$3 \quad$ Maatregel extra weidegang $\quad 13$

$\begin{array}{lll}3.1 & \text { Weidegangpakketten } & 13\end{array}$

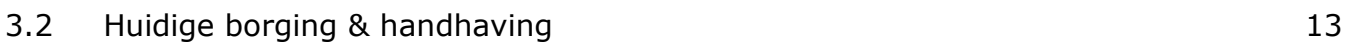

3.3 CO2 meting als alternatieve borgingsmethode? $\quad 15$

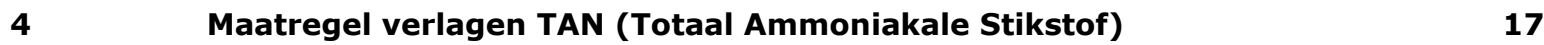

$\begin{array}{lll}4.1 & \text { Achtergrond } & 17\end{array}$

$\begin{array}{lll}4.2 & \text { Borging via de Kringloopwijzer } & 18\end{array}$

$5 \quad$ Conclusies en aanbevelingen $\quad 22$

$\begin{array}{lll}5.1 & \text { Conclusies } & 22\end{array}$

$\begin{array}{ll}5.2 & \text { Aanbevelingen voor beleid } \\ \end{array}$

$\begin{array}{ll}\text { Bronnen } & 23\end{array}$

$\begin{array}{lll}\text { Bijlage 1 Mogelijke weidegangpakketten } & 24\end{array}$

Bijlage 2 Resultaten literatuurstudie naar $\mathrm{CO}_{2}$-uitstoot uit de stal 26

$\begin{array}{llr}\text { Bijlage } 3 & \text { Onderzoek } \mathrm{CO}_{2} \text {-metingen } & 28\end{array}$

$\begin{array}{lll}\text { Bijlage } 4 & \text { Afleiden TAN-productie } & 33\end{array}$

Bijlage 5 Prestatiebeschrijving uitrijden van voldoende verdunde mest met een sleepvoet $\quad 35$

$\begin{array}{lll}\text { Bijlage } 6 & \text { Elektrische geleidbaarheid van rundveemest } & 38\end{array}$

$\begin{array}{ll}\text { Verdunning } 1: 0 \text { (onverdund) } & 41\end{array}$

$\begin{array}{ll}\text { Verdunning 3:1 } & 41\end{array}$

Verdunning 2:1 41

Verdunning $1: 1 \quad 42$ 



\section{Samenvatting}

Om bovenwettelijke maatregelen te kunnen verzilveren (hetzij via de PAS, hetzij via een Natuurbeschermingswet-vergunning of via keten- of gebiedsgerichte arrangementen) is het essentieel dat (de effecten van) maatregelen kunnen worden gemonitord, geborgd en/of gehandhaafd.

In deze studie zijn 3 borgingsmethodieken onderzocht:

- Voor het verdund uitrijden van mest

- Voor extra weidegang

- Voor het verlagen van de TAN

Voor de borging van het verdund uitrijden van mest is een goedkoop alternatief ontwikkeld voor de NVWA-LNV borgingssystematiek gebaseerd op twee flowmeters, een EC-meter en een datalogger. Dit alternatief is gebaseerd op EC-waarden van de mest. De EC-waarde blijkt een goede indicatie te geven voor de mate van verdunning. Deze methode blijkt veel goedkoper dan de LNV/NVWA-systematiek. Een ander groot voordeel is dat deze methode ook de verdunning die al in de stal of mestopslag heeft plaatsgevonden meeneemt. Voor de beleidsmatige implementatie is van belang welke mate van zekerheid het beleid wenst. Bij een hoge mate van zekerheid hoort een lage EC-waarde. Maar een lage EC-waarde leidt ook tot een sterkere verdunning en dus meer werk en kosten voor de boer.

Ook de ontwikkelde methode om weidegang te borgen via het CO2-gehalte in de stal lijkt veelbelovend. De methode is nauwkeurig en goedkoop. De methode werkt het best op bedrijven met all-in, all-out beweiding. Voor bedrijven met vrije koebewegingen moeten aanvullende rekenregels worden ontwikkeld die deze factor kunnen uitfilteren. Nader onderzoek naar de precieze benodigde technische invulling is nodig om dit borgingsmechanisme 'beleids-proof' te maken.

Tenslotte is een methode ontwikkeld om een veelheid aan voer- en managementmaatregelen om de ammoniakemissie terug te dringen, die moeilijk fysiek te borgen zijn, administratief te borgen. Al deze maatregelen leiden namelijk tot een verlaging van de TAN (Totale Ammoniakale Stikstof). Daarmee kan via de TAN het opgetelde effect van losse maatregelen worden bepaald. De TAN is onderdeel van de Kringloopwijzer (de BEA) en kan op deze wijze worden geborgd.

Managementmaatregelen verdienen een grotere plek in het ammoniakbeleid. Ze zijn goedkoop en goed inpasbaar. Het verdient aanbeveling de ontwikkelde borgingsmethodieken te betrekken bij het opnemen van de bijbehorende of onderliggende maatregelen in het beleid t.a.v. de PAS en Natuurbeschermingswet-vergunningen (plaatsing op de Rav-lijst).

De ontwikkelde borgingsmethoden zijn beleidsmatig van belang (met name voor het verdund uitrijden van mest), maar kunnen ook een rol spelen bij de borging van keten- of gebiedsgerichte arrangementen. Dat is uitgewerkt in de Proeftuinpublicaties:

- "Effect van het sleepvoetverbod op de ammoniakemissie"

- "Naar een ketengerichte aanpak om ammoniakemissie te reduceren. Ontwerp en toetsing"

- "Naar een integraal gebiedsgerichte aanpak om ammoniakemissie te reduceren. Ontwerp en pilot" 


\section{$1 \quad$ Inleiding}

\subsection{Waarom borgen?}

De Proeftuin Veenweiden heeft ingezet op een reductie van de ammoniakemissie van minimaal $25 \%$. Maar waarom zou een melkveehouder deze maatregelen nemen? Dan zijn twee trajecten van belang:

- Voldoen aan (toekomstige) wettelijke verplichtingen. Dan gaat het allereerst om verplichtende generieke maatregelen. Een voorbeeld is het sleepvoetverbod per 1 januari 2019, dat door melkveehouders in het veenweidegebied is beantwoord door mest verdund met water te gaan uitrijden. Maar ook voermaatregelen zouden in de toekomst een antwoord kunnen zijn op aanvullende verplichte maatregelen vanuit de (opvolger van de) PAS. Tenslotte kan het ook gaan om het voldoen aan de eisen voor een Natuurbeschermingswet- of Omgevingsvergunning, al dan niet in het kader van bedrijfsuitbreiding.

Een belangrijke route is bijlage 2 van de Regeling Ammoniak en Veehouderij (Rav). Als een maatregel voldoende wetenschappelijk kan worden onderbouwd en goed is te borgen/handhaven, kan deze een plek krijgen op deze lijst en worden meegenomen in het traject van vergunningverlening in Nederland.

Zonder opname in de bijlage 2 van de Rav kunnen maatregelen ook via een besluit van GS - via het Stikstofkader - in afzonderlijke provincies toepasbaar worden verklaard bij een

Natuurbeschermingswetvergunning. Ook dan is een wetenschappelijke onderbouwing en een goede borging \& handhaving noodzakelijk. De provincies Drenthe, Overijssel en Noord-Brabant hebben zo'n Stikstofkader.

- $\quad$ Verzilveren van bovenwettelijke inspanningen. Alles wat een melkveehouder vervolgens nog extra doet is bovenwettelijk. Ook dat kan hem wat opleveren, omdat veel voer- en managementmaatregelen ook baten opleveren voor de bedrijfsvoering, via lagere kosten, extra grasgroei en/of minder arbeidsinzet. Echter de praktijk leert dat de hoogte van deze financiële voordelen nu nog onvoldoende is om een grote groep melkveehouders in beweging te krijgen. Daarom heeft de Proeftuin ook gewerkt aan mogelijkheden om bovenwettelijke inspanningen te 'verzilveren' via transacties. Reductie van ammoniakemissie kan namelijk ook interessant zijn voor andere partijen als industrie/(lucht)-havens, zuivelketens, EU (inzet GLB gelden), banken (MVO beleid) of waterschappen. Ook deze partijen hebben er belang bij dat ammoniakemissies omlaag gaan ${ }^{1}$.

Tabel 1 Partijen en hun wensen/doelen en de daarbij passende ammoniak reducerende pakketten.

\begin{tabular}{lll} 
Partij & Wensen / doelen & Pakketten \\
$\begin{array}{l}\text { Industrie, (lucht)havens, } \\
\text { wegverkeer }\end{array}$ & $\begin{array}{l}\text { Gegarandeerde langjarige reductie } \\
\text { ammoniakemissie en CO2-uitstoot }\end{array}$ & Stal pakketten \\
\hline Waterschappen & Minder bodemdaling & Integrale pakketten \\
& Schoner oppervlaktewater & Onderwaterdrainage \\
\hline Zuivelketens & Integrale verduurzaming & Integrale pakketten \\
& Extra weidegang & Extra weidegang \\
\hline Banken & Integrale verduurzaming & Integrale pakketten \\
\hline EU & Integrale verduurzaming & Integrale pakketten \\
\hline
\end{tabular}

\footnotetext{
${ }^{1}$ Waarbij de vraag hoe bovenwettelijke inspanningen te verzilveren in andere Proeftuinpublicaties aan de orde komt:

- "Naar een integraal gebiedsgerichte aanpak om ammoniakemissie te reduceren. Ontwerp en pilot"

- "Mogelijkheden tot vermarkten reducties in ammoniakemissie in het westelijk veenweidegebied"

- "Naar een depositiegerichte aanpak van ammoniakemissies rond de Nieuwkoopse Plassen"
} 
Maar dit alles is alleen mogelijk bij een goede borging van maatregelen. De Proeftuin heeft daarom veel energie gestoken in uitwerking van deze borging. Dit rapport doet daarvan verslag.

\subsection{Om welke maatregelen gaat het?}

De proeftuin heeft gewerkt aan borging van de volgende maatregelen:

- Uitrijden van verdunde mest

- $\quad$ Extra weidegang

- Verlagen van de TAN

\subsection{Doelstelling}

Het doel van het onderdeel "Borgen en verzilveren" is om instrumenten te ontwikkelen waarmee in de Proeftuin Veenweide ontwikkelde/toegepaste ammoniakemissie reducerende maatregelen kunnen worden geborgd. Zodat melkveehouders deze maatregelen kunnen 'verzilveren', hetzij via een wettelijk traject of via gebieds-/ketengerichte arrangementen.

\subsection{Leeswijzer}

Hoofdstuk 2 beschrijft de maatregel uitrijden verdunde mest. Hoofdstuk 3 de maatregel extra weidegang. Hoofdstuk 4 de maatregel verlagen TAN. Hoofdstuk 5 bevat conclusies en aanbevelingen. 


\section{Maatregel verdunnen van mest bij uitrijden}

\section{$2.1 \quad$ Aanleiding}

Vanaf 1 januari 2019 is het niet meer toegestaan om onverdunde mest met een sleepvoetbemester uit te rijden. Wie nog wel met een dergelijke machine het land op wil, moet de mest met 33 procent water verdunnen, ofwel: twee delen mest op 1 deel water. Bij controle met het blote oog is wel vast te stellen of mest is verdund, maar niet de mate waarin. Een borgingssysteem is dan nodig.

Het ministerie van LNV en de NVWA hebben - in samenwerking met de Proeftuin Natura2000 Overijssel en de Proeftuin Veenweiden - een borgingssystematiek ontwikkeld met twee flowmeters, een EC-meter en datalogging. Dit systeem is nauwkeurig, maar ook erg duur (ca. 10.000 euro per machine). Voor de prestatie-beschrijving, zie bijlage 5. Een loonwerker kan die investering nog wel betalen, maar een veehouder met een eigen giertank niet. Bovendien stuurt dit system op een vaste verhouding in het volume water en mest, ongeacht of de mest vooraf is verdund. Daarmee houdt het systeem dus geen rekening houden met mest die al in de stal is verdund.

Binnen de Proeftuin Veenweiden is daarom gezocht naar een goedkoper alternatief, in de vorm van meting van de EC-waarde, via een datalogger of gps op de EC-meter. Verwachte kosten: zo'n 2.500 euro. De inzet is om te komen tot één specifieke EC-waarde voor een verdunning van 2:1, die in de wetgeving wordt opgenomen. De hamvraag is of dat wel mogelijk is bij een grote variatie aan mestsoorten.

In het onderzoek is mest verzameld van 29 melkveebedrijven. Daarbij bleek het lastig om onverdunde mest te vinden. Veel boeren blijken hun mest al in de mestkelder te verdunnen. De inzet van de Proeftuin was om met meer dan $85 \%$ zekerheid te kunnen aangeven dat de mest bij een bepaalde ECwaarde voldoende is verdund.

\subsection{Twee borgingssystemen vergeleken}

In onderstaande figuur en tabel wordt de EC-meter vergeleken met de NVWA/LNV borgingssystematiek. 


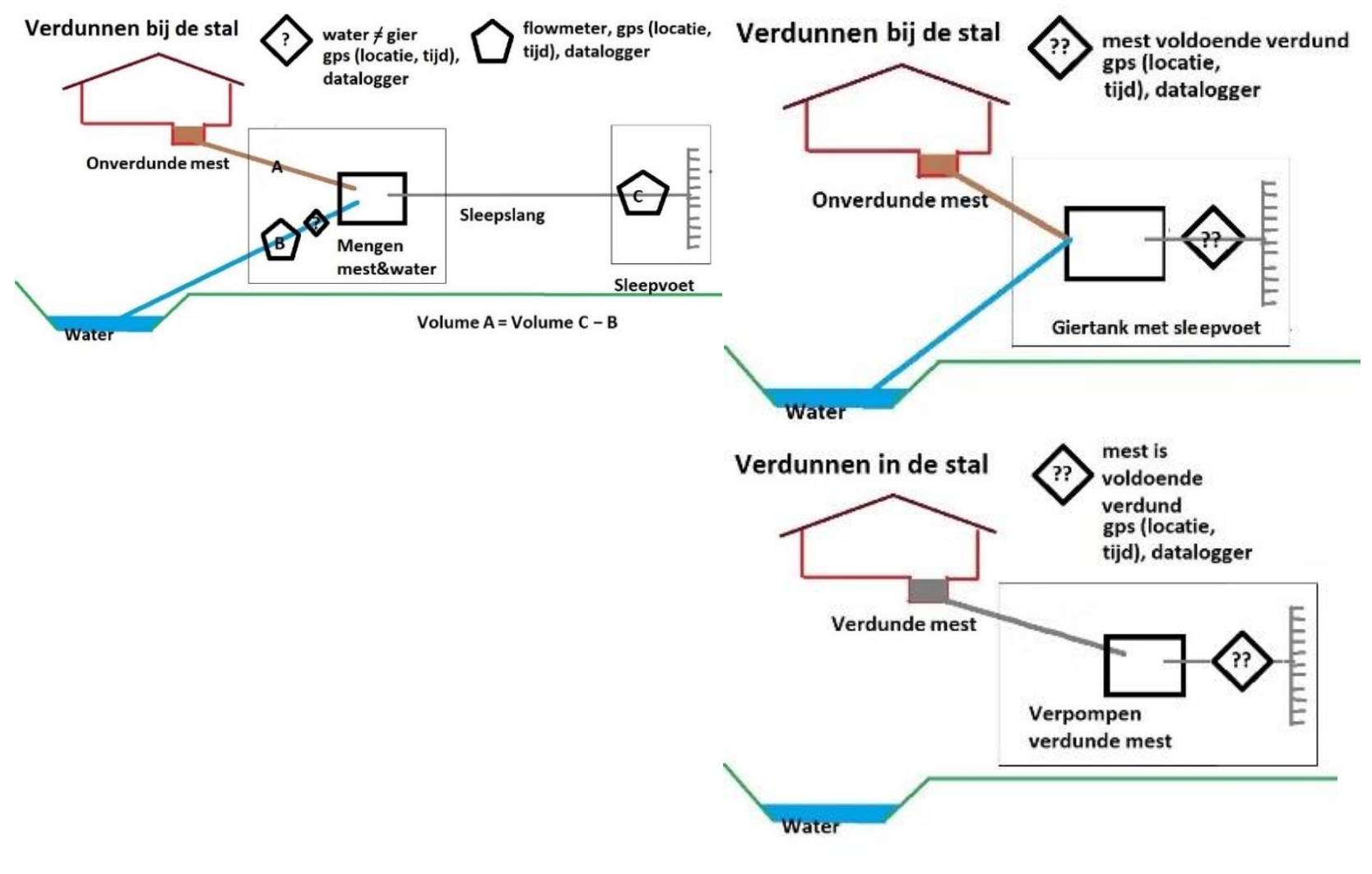

Figuur $1 \quad N V W A / L N V$ borging verdunning versus het alternatief van de Proeftuin.

Tabel 2 NVWA/LNV variant van borgen versus het alternatief van de Proeftuin Veenweiden.

\section{NVWA/LNV variant}

- $\quad$ Twee flowmeters. Bij ingang van water en bij uitgang van verdunde mest.

- Controle of volume water minimaal 0,5x het volume mest is.

- $\quad$ EC meter bij ingang van water (voorkomen gier bijmengen)

- Datalogger/GPS op flowmeters en EC-meter.

- $\quad$ Alleen water toevoegen bij uitrijden mogelijk

- $\quad$ Duur (+/- € 10.000)

- Nauwkeurig

\section{Proeftuin Veenweiden alternatief}

- $\quad$ EC-meter bij uitgang van verdunde mest

- Controle of mest max een bepaalde EC-waarde heeft

- Datalogger/GPS op EC-meter

- $\quad$ Ook water toevoegen in de mestkelder mogelijk

Bij verdunnen in stal, moet de mest nog een keer extra
- $\begin{aligned} & \text { onderbouwd te geven } \\ & \text { Nog onduidelijk is of het in de praktijk voldoende } \\ & \text { nauwkeurig kan zijn. }{ }^{*} \text { ) }\end{aligned}$
verhouding in het volume water /mest, ongeacht of de
mest al vooraf is verdund.

* De Proeftuin Veenweiden gaat hiertoe samen met een machinebouwer/loonwerker een praktijkproef uitvoeren.

De eerste vraag is dan of het bij een grote variatie aan mestsoorten mogelijk is om de EC-waarde voldoende garantie te geven dat de mest voldoende verdund is? In onderstaande grafiek zijn de ECwaarden van de 29 mestmonsters bij verschillende mate van verdunning weergegeven (1:0= onverdunde mest, 2:1 = mest verdund in de verhouding 1 deel water op 2 deel mest. En 1:1 = mest verdund met evenveel water). 


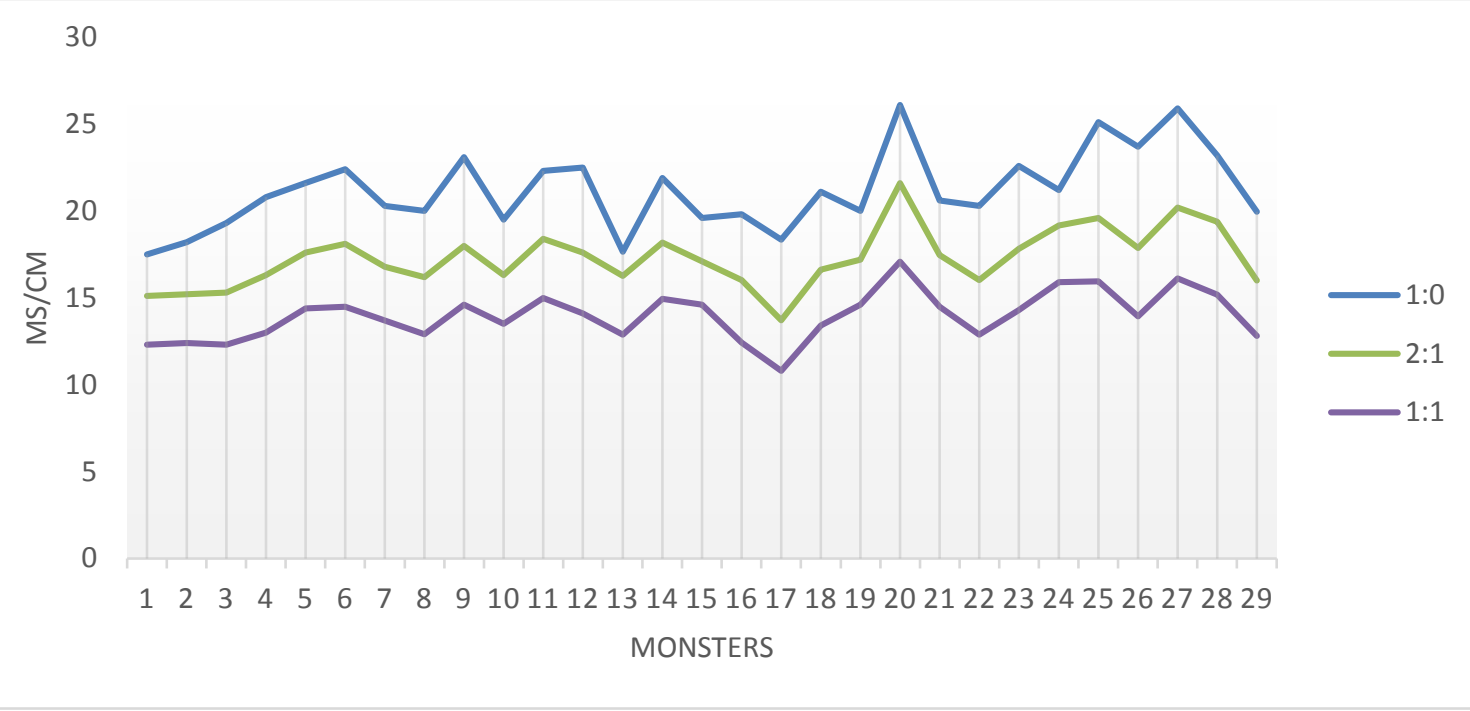

Figuur 2 De EC waarde (in Ms/cm) van 29 mestmonsters bij verschillende mate van verdunning.

Uit de grafiek blijkt de EC waarde een goede indicator voor verdunning te zijn: hoe groter de verdunning, hoe lager de EC waarde. En dat is eigenlijk logisch, omdat water slechter geleid dan (de zouten in de) mest.

De volgende vraag is bij welke EC-waarde er een grote mate van zekerheid is dat de mest minimaal is verdund met 1 deel water op 2 delen mest. Daarvoor is dataset van de 29 monsters statistisch geanalyseerd. Zie voor de details bijlage 6. De verdeling van EC-waarden was als volgt:

Tabel 3 gemiddelde, variantie en standaard deviatie van de EC-waarde bij de 29 monsters.

\begin{tabular}{llll} 
verdunning & $\begin{array}{l}\text { gemiddelde EC-waarde } \\
(\mathrm{ms} / \mathrm{cm})\end{array}$ & Variantie (sd2) & standaard dev (sd) \\
\hline $1: 0$ & 21.19 & 5.11 & 2.26 \\
\hline $2: 1$ & 17.28 & 2.86 & 1.69 \\
\hline $1: 1$ & 13.97 & 1.94 & 1.39 \\
\hline
\end{tabular}

De gemiddelde EC-waarde bij verdunning 2:1 was 17,28. Vanwege de spreiding daarbij is het voor zekerheid omtrent voldoende verdunning nodig om uit te gaan van een lagere waarde. Maar hoeveel lager?

In onderstaande tabel is aangegeven welk percentage zekerheid je hebt bij een bepaalde EC-waarde. Zo zou de EC-waarde lager dan $16.40 \mathrm{mS} / \mathrm{cm}$ moeten zijn om met $85 \%$ zekerheid te kunnen zeggen dat de mest voldoende verdund is.

Tabel 4 Toename van de betrouwbaarheid (Power) bij een lagere EC-waarde.

\begin{tabular}{ll} 
EC gehalte $\mathrm{ms} / \mathrm{cm}$ & Power $(\%)$ \\
16.00 & 99.25 \\
\hline 16.10 & 98.28 \\
\hline 16.20 & 96.37 \\
\hline 16.30 & 93.02 \\
\hline 16.40 & 87.67 \\
\hline 16.50 & 79.95 \\
\hline 16.60 & 69.89 \\
\hline 16.70 & 58.02 \\
\hline
\end{tabular}


Uiteindelijk gaat het hier ook om een politieke keuze. Hoeveel zekerheid wil de overheid? En weegt dat op tegen het feit dat een grotere zekerheid er toe leidt dat er vaker onnodig extra verdunning plaats zal gaan vinden? 


\section{$3 \quad$ Maatregel extra weidegang}

\subsection{Weidegangpakketten}

Weidegang draagt bij aan minder ammoniakemissie, zowel in het veld als in de stal:

- $\quad$ Bij weiden worden faeces en urine niet gemengd en treedt dus nauwelijks ammoniakemissie op

- $\quad$ Er hoeft een minder groot volume aan mest te worden uitgereden

- In de stal komt minder verse mest op de roosters en in de kelder terecht

Er is momenteel sprake van één weidegangpakket op bijlage 2 van de Rav waarbij het aantal uren weidegang minimaal 720 uur bedraagt. Mede vanuit de Proeftuin Veenweiden zijn voorstellen ingediend om daar aanvullende pakketten aan toe te voegen voor extra uren weidegang bovenop deze 720 uur. (zie bijlage 1). Daarnaast is behoud van weidegang een van de duurzaamheidsthema's binnen de duurzame zuivelketen. Een afdoende borging en handhaving is in beide trajecten cruciaal.

Tabel 5 Maatregel extra weidegang

\begin{tabular}{llll} 
Maatregel & Emissiereductie & Werkingsmechanisme & Borging \\
Extra weidegang & $5-20 \% *)$ & Minder verse mest op de mestkorst & Via o.a. \\
(stal effect) & & in de kelder / Minder besmeurd & certificering/technische \\
& & oppervlakte in stal & borging/CO2 concentratie $* *)$ \\
\hline
\end{tabular}

*) extra t.o.v. 720 uur weidegang.

**) De Proeftuin borduurt hier voort op het SBIR traject met Natuurweide/NZO/LTO om extra weidegang op bijlage 2 van Rav te krijgen.

\subsection{Huidige borging \& handhaving}

Om de aanvullende emissiereductie op het stalsysteem ook daadwerkelijk mee te kunnen nemen in een vergunning-verleningstraject in het kader van de Natuurbeschermingswet, is het zaak om deze extra uren weidegang te kunnen borgen en te handhaven. Hiervoor is momenteel een soort 'a la carte' aanpak in gebruik, waarbij de melkveehouder kan kiezen uit een mix van borgingsmaatregelen. Hoe die mix er concreet uit kan zien is te zien in tabel 6 . 
Tabel 6 Mix van borgingsmaatregelen voor een 'a la carte' aanpak.

\begin{tabular}{|c|c|c|c|c|c|c|c|}
\hline & \multicolumn{2}{|c|}{$\begin{array}{l}\text { Weidezuivel } \\
720 \text { uur }\end{array}$} & \multirow{2}{*}{$\begin{array}{r}\text { Biologische } \\
\text { zuivel }\end{array}$} & \multicolumn{3}{|c|}{ Urenstaffel } & \multirow{2}{*}{$\begin{array}{c}\begin{array}{c}\text { Onbeperkt } \\
\text { weiden }\end{array} \\
>3500 \text { uur }\end{array}$} \\
\hline & Huidig & Streven & & 1440 uur & 2160 uur & 2880 uur & \\
\hline \multicolumn{8}{|l|}{$\begin{array}{l}\text { Periodieke beoordeling } \\
\text { bedrijfsopzet }\end{array}$} \\
\hline \multicolumn{8}{|l|}{ Weide-kalender } \\
\hline \multirow{2}{*}{\multicolumn{8}{|c|}{ Technische borging }} \\
\hline & & & & & & & \\
\hline \multicolumn{8}{|l|}{ Signaleringssysteem } \\
\hline Vrije-keuzestal / AMS *) & n.v.t. & & n.v.t. & & n.v.t. & n.v.t. & n.v.t. ** \\
\hline $\begin{array}{l}\text { Controle-regime (visueel en } \\
\text { fysiek) }\end{array}$ & Beperkt & Beperkt & Beperkt & Beperkt & Matig & Intensief & Beperkt \\
\hline
\end{tabular}

Aanwezigheid geldig certificaat afdoende

Certificaat met borging

bepaalt aantal uren weide-

gang

*) Bij een vrije-keuzestal kunnen de melkkoeien vrij in en uit de stal lopen (al dan niet met gedwongen koeverkeer via het AMS). In het geval van een

**) Onwaarschijnlijke variant.

vrije-keuzestal, zijn technische borgingssystemen noodzakelijk om deel te nemen aan de urenstaffel.

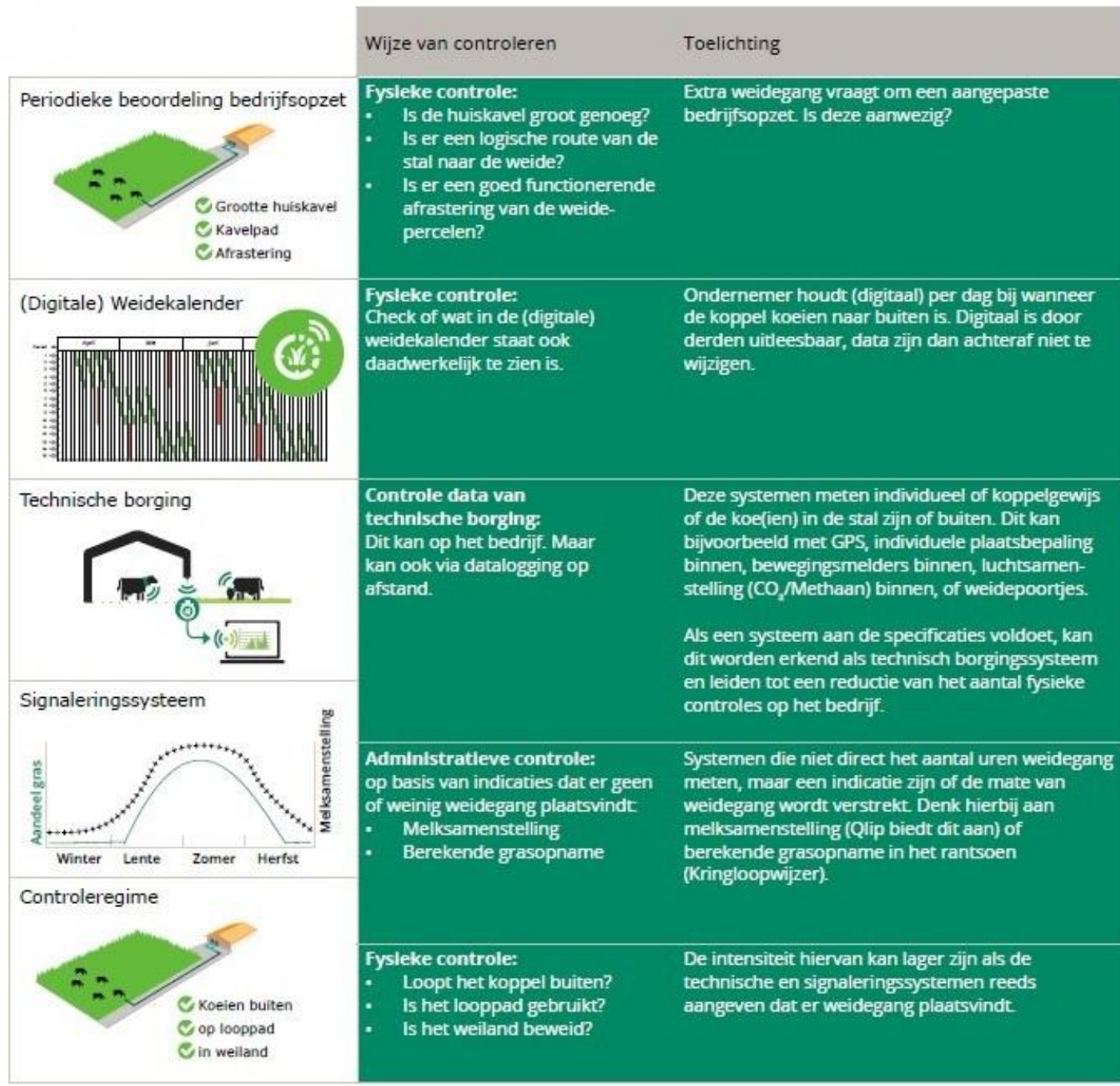




\subsection{CO2 meting als alternatieve borgingsmethode?}

\section{Aanleiding}

De Duurzame zuivelketen heeft het initiatief genomen om te komen tot een lijst met technische borging-systemen die het mogelijk maken om (deel-)weidegang en weidegang in combinatie met een Automatisch Melksysteem (AMS) te borgen. Het gaat dan om systemen met sensoren die per individueel dier meten of het dier naar buiten of naar binnen gaat. Dit is een nauwkeurige techniek, met één groot nadeel: hij is duur.

De Proeftuin Veenweiden is door zuivelverwerker De Zuivelmakers uit Lopik daarom benaderd om te zoeken naar een goedkoper alternatief. Met als denkrichting het monitoren van $\mathrm{CH} 4$ of $\mathrm{CO} 2-$

concentraties in de stal om daarmee te kunnen controleren hoeveel dieren er (niet) in de stal zijn. Bestaande $\mathrm{CH} 4$ meters meten geen absolute concentraties, maar waarschuwen bij een te hoge $\mathrm{CH} 4$ concentratie. CO2-meters meten wel absolute concentraties en zijn bovendien goedkoper. Daarom is het onderzoek toegespitst op $\mathrm{CO} 2$.

De onderzoeksvraag was of het met CO2 metingen op 1 punt in de stal vast te stellen of de koeien in de stal of buiten zijn (in de wei lopen)?

\section{Resultaten literatuurstudie}

Uit een eerste literatuurstudie bleek dat $\mathrm{CO} 2$ die de dieren uitademen, zich homogeen verdeelt over de stal. En dat de hoeveelheid $\mathrm{CO} 2$ die melkkoeien produceren afhankelijk is energiestofwisseling. En dat is weer afhankelijk van voerniveau, samenstelling van het voer, omgevingstemperatuur en het niveau van activiteit van de dieren. (zie bijlage 2 ).

\section{Pilot: Proof of Principle}

Om te kijken of CO2-metingen ook daadwerkelijk een goede indicatie geven van het aantal dieren dat zich (niet) in de stal bevindt, is vervolgens op twee melkveebedrijven onderzoek gedaan. Het ene melkveebedrijf (in Benschop) hanteert all in- all out voor beweiding en het andere bedrijf (in Bodegraven) heeft vrij koeverkeer en vanaf 7 juni dag en nacht weidegang.

Dat leverde volgende resultaten op:

- Bij all-in-, all out beweiding (Benschop) is een duidelijk onderscheid te zien in CO2-gehalte (ppm) wanneer de koeien allemaal binnen of buiten zijn (figuur 3).

- Bij vrij koeverkeer (Bodegraven) is het patroon minder duidelijk (figuur 4). 
CO2 (ppm) bij koeien in-uit-in stal, 7 juni '18

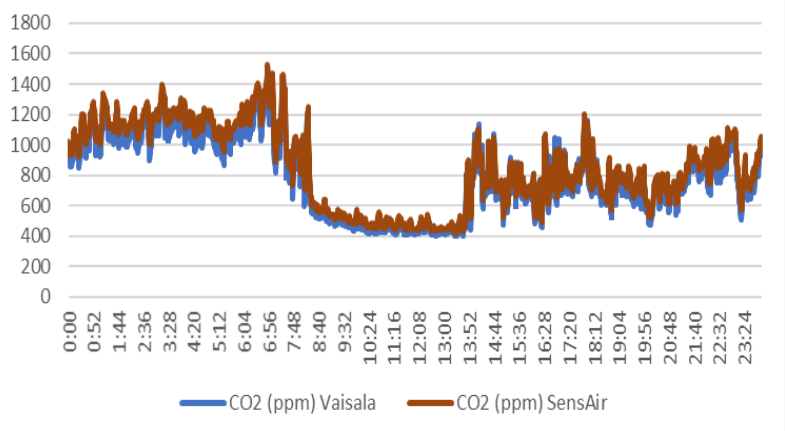

CO2 (ppm) bij koeien in-uit-in stal, 15 juni '18

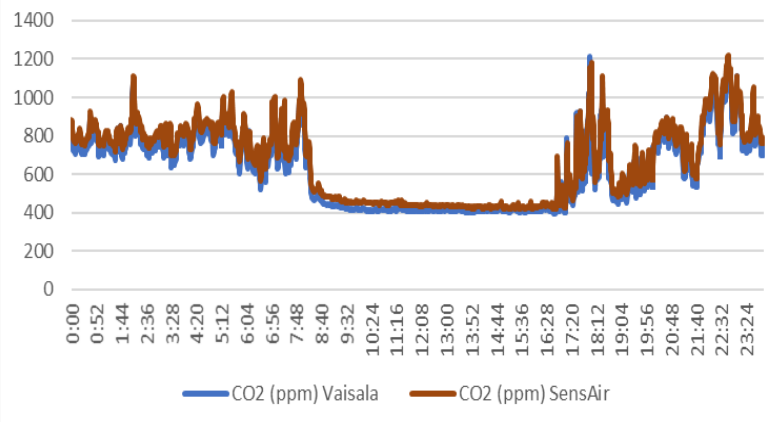

Figuur 3 (Benschop)
CO2 (ppm) bij vrij koeverkeer, 7 juni '18

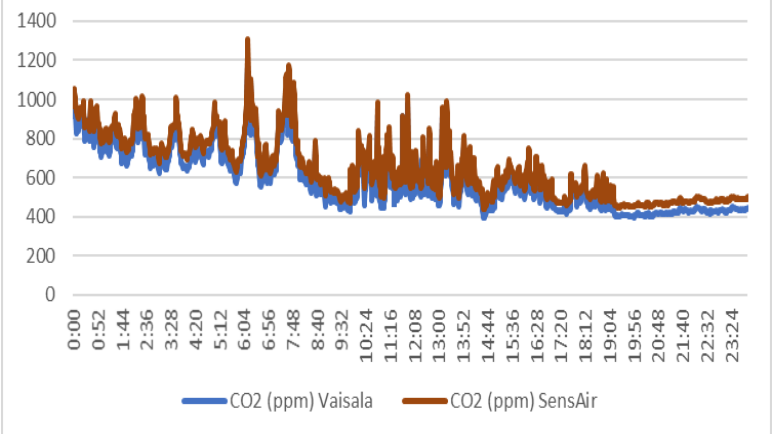

CO2 (ppm) bij vrij koeverkeer, 15 juni '18

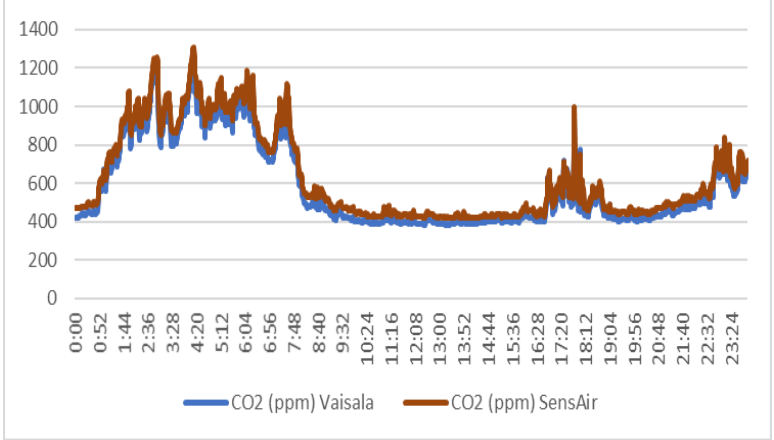

Figuur 4

Wanneer de koeien allemaal buiten zijn zakt het CO2 gehalte telkens terug naar ong. 400 ppm. Alhoewel het verschil binnen/buiten duidelijker is op het bedrijf met all-in all-out, ligt de ondergrens op beide bedrijven op ca. 400 ppm op alle meetdagen. Het verschil in CO2 tussen binnen en buiten blijkt ook een relatie te hebben met de temperatuur: bij hogere temperaturen is de $\mathrm{CO} 2$ productie hoger waardoor het verschil tussen alle koeien in of uit de stal groter en duidelijker is.

Uit de pilot blijkt dat met CO2-metingen op een bedrijf met:

- all in-all out duidelijk verschil is aan te tonen tussen wanneer de koeien in de stal of buiten zijn

- $\quad$ vrij koeverkeer dit lastiger is, vooral als de koeien dicht bij huis weiden (groter aantal koebewegingen). De volgende uitdaging is om rekenregels te ontwikkelen die data rond koebewegingen omzetten naar het aantal koeien in de stal en vervolgens koppelen aan de $\mathrm{CO} 2$ metingen.

Voor de gedetailleerde onderzoeksresultaten, zie bijlage 3.

Deze resultaten zijn dusdanig veelbelovend dat het uiterst zinnig is om het onderzoek voort te zetten. 


\section{$4 \quad$ Maatregel verlagen TAN (Totaal Ammoniakale Stikstof)}

\subsection{Achtergrond}

Op een melkveebedrijf zijn heel veel voer- en managementmaatregelen voorhanden om de ammoniakemissie te verminderen. Het blijkt echter lastig om deze maatregelen afzonderlijk te borgen. Ook werken veel van deze maatregelen op elkaar in: soms versterkt ze elkaar, soms ook niet. Per maatregel een reductiepercentage toekennen is dus lastig. En de effecten mogen bij meerdere maatregelen ook niet zomaar opgeteld worden.

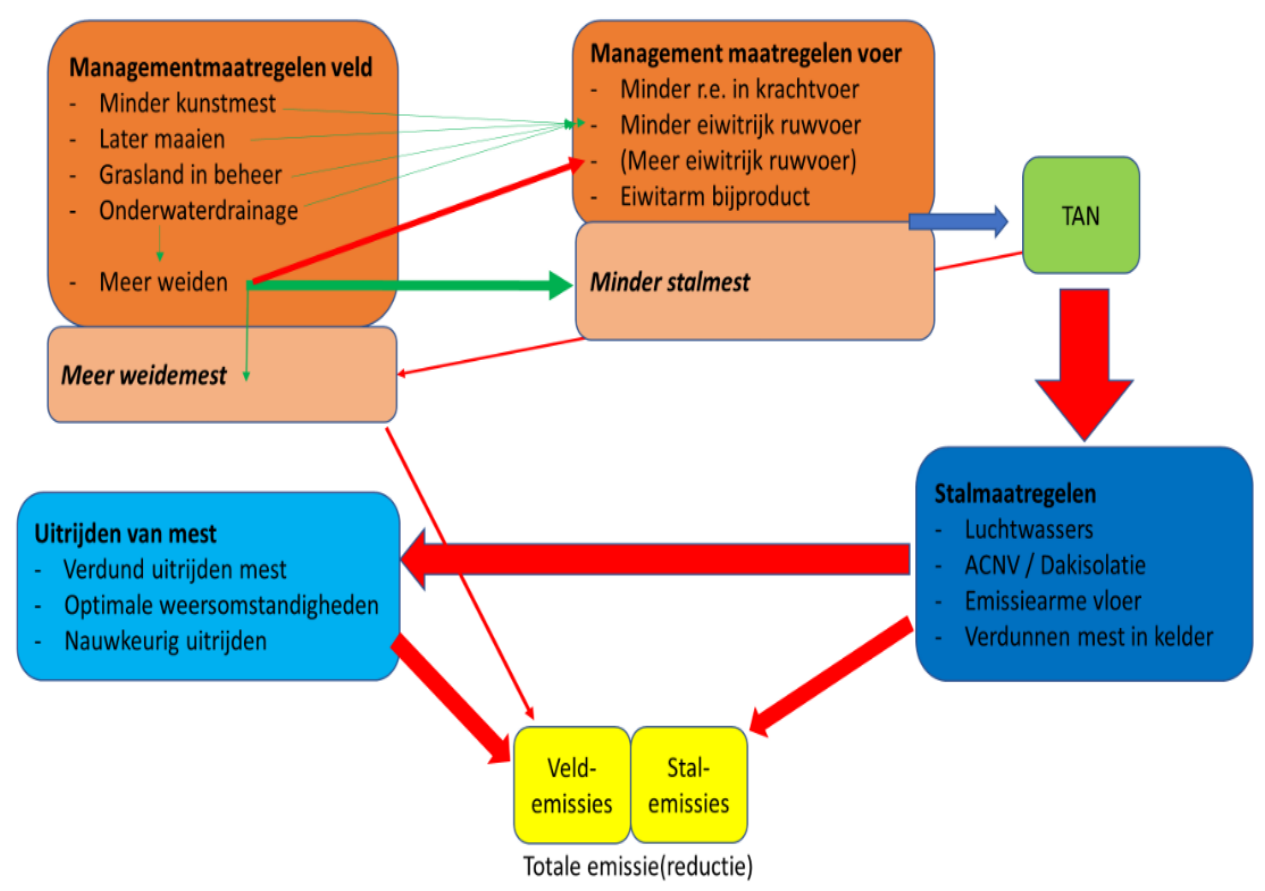

Dat maakt borging en handhaving lastig. Het is tot nu toe vrijwel onmogelijk gebleken om (combinaties van) voer- en management-maatregelen op melkveebedrijven bij de vergunningverlening te honoreren.

Echter al deze maatregelen leiden tot verlaging van de TAN (totale ammoniakale stikstof) op een bedrijf. Daarmee is de TAN een maat voor de optelsom van al die afzonderlijke voer- en managementmatregelen. Bovendien zit in de TAN ook het effect van elkaar tegenwerkende of versterkende maatregelen.

Dat maakt de TAN heel goed bruikbaar om de reductie van ammoniakemissie op een bedrijf te monitoren.

Het inzetten op verlagen van de TAN wordt daarmee een soort overkoepelende 'meta' maatregel, onder meer voor de volgende maatregelen die op de Proeftuin zijn beproefd. 
Tabel 7 Overzicht van maatregelen uit de Proeftuin Veenweiden die via de TAN zijn te borgen.

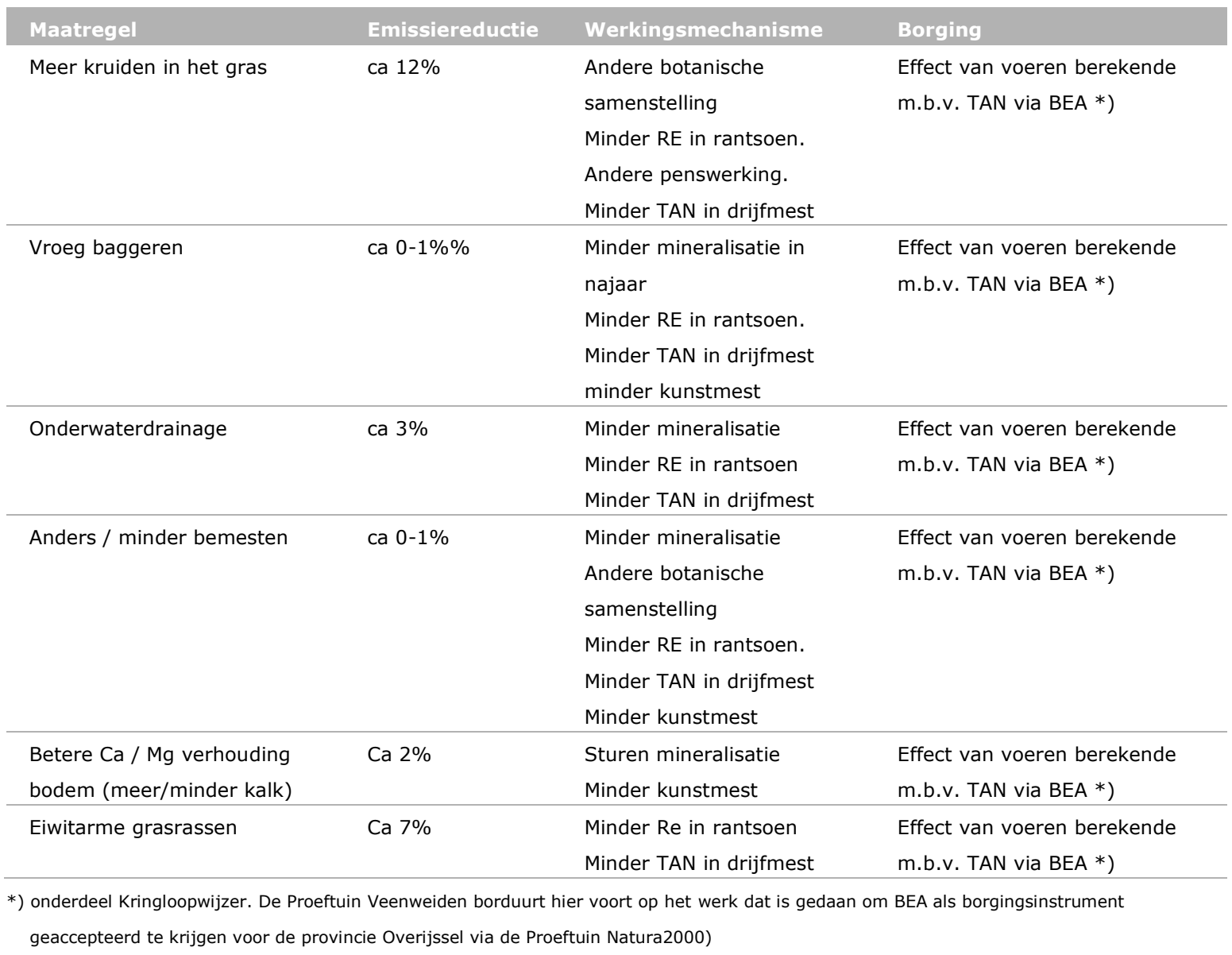

\subsection{Borging via de Kringloopwijzer}

De TAN is opgenomen in de (Bedrijfsspecifieke Emissie Ammoniak (BEA) van de) Kringloopwijzer Maar hoe betrouwbaar zijn de Kringloopwijzer en BEA als het gaat om het borgen van een verlaging van de TAN?

Achtergrond van de Kringloopwijzer en de BEA

Achtergrond, referenties en rekenmethodiek van de Kringloopwijzer zijn vastgelegd Sebek et al., 2017. De BEA is onderdeel van de Kringloopwijzer en is feitelijk een N-stromenmodel dat werkt op basis van de Totaal Ammoniakale Stikstof (TAN)-productie op het bedrijf. BEA volgt NEMA (Nationaal Emissiemodel Ammoniak) v.w.b. de relatie TAN-productie/ammoniakemissie. Een lagere TANproductie betekent een lagere ammoniakemissie.

Op basis van landelijke gemiddelden die gebruikt worden in NEMA en de Rav (Regeling ammoniakemissie veehouderij) kan voor ieder type rundveestal een standaard TAN-productie per dierplaats worden berekend. Met de BEA is het mogelijk de gerealiseerde TAN-productie in kg per dierplaats te berekenen. Dit betreft dus de waarde van het eigen bedrijf waarbij het effect van genomen voer en managementmaatregelen op de TAN-productie is meegenomen. Als deze onder de opgestelde standaardproductie ligt, dan is de ammoniakemissie als gevolg van de lagere TANproductie ook lager. Deze wijze van borgen is te gebruiken bij elk staltype.

Voer- en managementmaatregelen zorgen voor een verlaging van de TAN-productie en een vermindering van de TAN in de mest. Een lagere TAN-productie leidt tot een lagere ammoniakemissie uit de stal en/of mestopslag en een lagere TAN in mest leidt tot minder ammoniakemissie bij het uitrijden. Welke maatregelen daarvoor precies genomen worden is niet relevant. Wel relevant is het effect van deze mix van maatregelen op de bedrijfsspecifieke TAN-productie per dierplaats (kg). Het 
totale reducerende effect van de maatregel 'voer- en managementmaatregelen via BEA' kan dan ook variëren van 0 tot meer dan $50 \%$ t.o.v. de standaard TAN-productie.

\section{Wijze van borging}

De wijze waarop borging via BEA werkt is uitgewerkt in onderstaand kader.

\section{Borging via BEA}

De in de BEA gebruikte emissiefactoren in het gebruikte $\mathrm{N}$-stromenmodel zijn afkomstig van NEMA en RAV (voor huisvesting), . waarmee de TAN-stroom in de BEA is geborgd. De emissies volgens NEMA worden periodiek geactualiseerd naar de nieuwste kennis en voor melkvee is de meest recente actualisatie gerapporteerd door van Bruggen e.a. (2014). Hieronder zijn de geactualiseerde emissies volgens van Bruggen e.a. voor met meest voorkomende (90\%) rundveestaltype A1.100 weergegeven. Daarbij wordt voor weiden onderscheid gemaakt tussen beperkt (1352 uur/jaar) en onbeperkt weiden (3.380 uur/jaar.

Van Bruggen et al (2014) geven een TAN-emissiefactor voor het standaard Rav staltype met een vastgestelde ammoniakemissie in $\mathrm{kg}$ per dierplaats per jaar. Die emissie geldt voor een gemiddeld rantsoen en een gemiddelde veestapel. Met de TAN-emissiefactor (NEMA) en de ammoniakemissie in $\mathrm{kg}$ per dierplaats per jaar (Rav) is een standaard TAN-productie te berekenen (zie onder). Die standaard TAN-productie is door voer- en managementmaatregelen te verkleinen en te berekenen met de BEA-methodiek.

\begin{tabular}{l|l} 
Staltype A1.100 drijfmest & Kg NH3 per dierplaats per jaar \\
\hline Permanent opstallen & 13,0 \\
\hline Beperkt weiden & 11,7 \\
\hline Onbeperkt weiden & 9,9 \\
\hline
\end{tabular}

De emissiefactor voor TAN is constant binnen de in Nederland voorkomende variatie in TANproductie en ammoniakemissie (van Bruggen e.a., 2014), zodat x\% minder TAN ook x\% minder ammoniakemissie geeft. Daardoor is het mogelijk om het effect van voer- en managementmaatregelen in de Rav mee te nemen door de vastgelegde ammoniakemissie te corrigeren voor het niveau van de TAN productie door vermenigvuldiging met het quotiënt van de gerealiseerde TAN en de standaard TAN ( = Rav emissie * [TAN-BEA / standaard TAN] ).

De standaard TAN-productie per dierplaats is voor ieder Rav staltype te gebruiken. Eenvoudigweg omdat deze niet afhankelijk is van staltype maar van veestapel en voermanagement. Voor alle staltypen in de Rav is de ammoniakemissie gebaseerd op dezelfde veestapel en hetzelfde voermanagement en dus op dezelfde hoeveelheid TAN $(\mathrm{kg})$.

Voor de methode om een standaard TAN-productie af te leiden en het berekenen van de ammoniakemissie per dierplaats per jaar wordt verwezen naar bijlage 4 .

De gerealiseerde TAN-productie per dierplaats op jaarbasis is m.b.v. het BEA deel binnen de Kringloopwijzer achteraf te berekenen. Daarmee is dus ook te berekenen of de gewenste emissiereductie via 'voer- en managementmaatregelen' is gerealiseerd.

Om tijdens de rit te kunnen monitoren hoe de TAN zich cumulatief ontwikkelt, heeft de Proeftuin Natura2000 Overijssel de 'Navigator' ontwikkeld. Opdat de melkveehouder desgewenst aanvullende maatregelen kan nemen om aan het eind van het jaar de gewenste emissie reductie te realiseren. 


\section{Betrouwbaarheid van de borging en handhaving}

Controle van de maatregel kan gebeuren op basis van de data in de Kringloopwijzer. Het vullen van de kringloopwijzer vindt zoveel mogelijk plaats op basis van een digitale databank. Door het gebruik van een digitale databank kun er geen invoerfouten gemaakt worden bij het 'overtikken' van gerapporteerde data. De BEX (Bedrijfsspecifieke Excretie) maakt gebruik van dezelfde data. De NVWA haalt daar de 'uitbijters' uit via een geautomatiseerd systeem.

Voor het beschreven gebruik van BEA (= de berekening van het effect van voermaatregelen op de ammoniakemissie), is niet het gehele rekenprogramma van BEA nodig. Slechts het deel dat de TANproductie berekent. De TAN-productie wordt in BEA berekend uit de volgende gegevens:

1. Samenstelling veestapel d.w.z. aantal dierdagen in de categorieën melkvee, jongvee jonger dan 2 jaar en overige vee ouder dan 2 jaar (jongvee en opfokstieren)

2. Voeropname veestapel in kilogram droge stof per jaar uitgedrukt per voedermiddel

3. Chemische samenstelling van de gebruikte voedermiddelen (droge stof, ruw eiwit en ruw as)

4. Melkproductie in kg melk per jaar

5. Melksamenstelling ( $\mathrm{N}$-gehalte)

Deze data worden in de Kringloopwijzer met voldoende nauwkeurigheid verzameld en de meeste worden digitaal verkregen (zie tabel 5 uit Holster et al 2015), met de volgende classificaties:

- Beschikbaar: beschikbaar $(+)$, beschikbaar maar momentopname $(0)$, niet beschikbaar $(-)$

- Digitaal: digitaal beschikbaar $(+)$, deels digitaal beschikbaar $(0)$, niet digitaal beschikbaar $(-)$

- Juistheid: goed te bepalen $(+)$, matig te bepalen $(0)$, slecht te bepalen $(-)$

- Controleerbaar: goed $(+)$, matig $(0)$, slecht $(-)$ controleerbaar

Uit tabel 5 blijkt dat de volgende data tbv de berekening van de TAN-productie:

- Digitaal verzameld worden met grote juistheid (tussen haakjes de benaming in tabel 5)

- Samenstelling veestapel (veestapel)

- Voeropname van de veestapel te berekenen en chemische samenstelling voedermiddelen (aanleg, voorraden voer)

- Melkproductie en melksamenstelling (melklevering).

- Niet-digitaal verzameld worden met grote juistheid (tussen haakjes de benaming in tabel 5)

- Voeropname (beweiding en zomerstalvoedering)

- Voeropname (afvoer eigen geteelde producten)

- Voeropname (verbruik niet-BEX producten)

- Niet-digitaal verzameld worden met geringe juistheid (tussen haakjes de benaming in tabel 5)

- Voeropname (aanvoer ruwvoer)

Omdat de kringloopwijzer over meerdere jaren wordt bijgehouden, zijn de data m.b.t. mest- en voerhoeveelheden niet meer tussen jaren te 'manipuleren'. 
Tabel 5 Indicatieve beoordeling van de invoergegevens van de KringloopWijzer

\begin{tabular}{|c|c|c|c|c|}
\hline Input & Beschikbaar & Digitaal & Juistheid & Controleerbaar \\
\hline Veestapel & + & + & + & + \\
\hline Overige graasdieren & + & 0 & + & + \\
\hline Melklevering & + & + & + & + \\
\hline Soort mest & + & - & + & + \\
\hline Aan-en afvoer mest & + & + & + & + \\
\hline Voorraden mest & + & 0 & + & 0 \\
\hline Toedieningsmethode drijfmest & + & - & + & 0 \\
\hline Huisvesting & + & - & + & + \\
\hline Aanvoer, voorraad kunstmest & + & 0 & + & 0 \\
\hline Kunstmest toediening & + & - & + & - \\
\hline Grond & + & + & + & + \\
\hline Bodem & + & 0 & + & + \\
\hline Klaver & 0 & - & - & - \\
\hline Beweiding + zomerstalvoeren & + & - & + & 0 \\
\hline Aanleg, voorraad voer & + & + & + & + \\
\hline Afvoer eigen geteelde producten & + & - & + & 0 \\
\hline $\begin{array}{c}\text { Verbruik niet-BEX-producten } \\
\text { nieuwe invoergegevens sinds } \\
\text { versie 2014.06 }\end{array}$ & + & - & + & 0 \\
\hline Toediening mest aan gewassen & + & - & + & 0 \\
\hline Gebruiksnormen fosfaat verleden & + & + & + & + \\
\hline Teeltwijze gewassen & + & - & + & 0 \\
\hline Vanggewassen & + & - & + & 0 \\
\hline Aanvoer ruwvoer & + & - & 0 & 0 \\
\hline
\end{tabular}

\section{Sanctionering}

Bij overschrijden van de TAN - zoals afgesproken in de Natuurbeschermingswetvergunning - is het zaak dit te beschouwen als een economisch delict. De bijbehorende stevige boete werkt dan corrigerend. 


\section{$5 \quad$ Conclusies en aanbevelingen}

\section{$5.1 \quad$ Conclusies}

1. Om bovenwettelijke maatregelen te kunnen verzilveren (hetzij via de PAS, via de NB-vergunning of via keten- of gebiedsgerichte arrangementen) is het essentieel dat (de effecten van) maatregelen kunnen worden gemonitord, geborgd en/of gehandhaafd.

2. Voor de borging van het verdund uitrijden van mest is een goedkoop alternatief ontwikkeld voor de bestaande NVWA-LNV borgingssystematiek. Dit alternatief is gebaseerd op EC-waarden van de mest. De EC-waarde blijkt een goede indicatie te geven voor de mate van verdunning. Een groot voordeel is dat deze methode ook de verdunning die al in de stal of mestopslag heeft plaatsgevonden meeneemt. Voor de beleidsmatige implementatie is van belang welke mate van zekerheid het beleid wenst. Bij een hoge mate van zekerheid hoort een lagere EC-waarde.

3. Een nieuwe betaalbare methode om weidegang te borgen via het CO2-gehalte in de stal lijkt veelbelovend. Nader onderzoek naar de precieze benodigde technische invulling is nodig om deze borging 'beleids-proof' te maken. De methode werkt het best op bedrijven met all-in, all-out beweiding. Voor bedrijven met vrije koebewegingen moeten aanvullende rekenregels worden ontwikkeld die deze factor kunnen uitfilteren.

4. Veel voer- en managementmaatregelen om de ammoniakemissie terug te dringen $n$ zijn moeilijk te borgen. Maar al deze maatregelen leiden wel tot een verlaging van de TAN (Totale Ammoniakale Stikstof). Daarmee kan via de TAN het opgetelde effect van meerdere afzonderlijke maatregelen worden bepaald. De TAN is onderdeel van de Kringloopwijzer (de BEA) en kan op deze wijze worden geborgd.

\subsection{Aanbevelingen voor beleid}

5. Managementmaatregelen verdienen een grotere plek ammoniakbeleid. Ze zijn goedkoop en goed inpasbaar. Het verdient aanbeveling de ontwikkelde borgingsmethodieken te betrekken bij het opnemen van de bijbehorende maatregelen in het beleid t.a.v. de PAS en Natuurbeschermingswetvergunningen (plaatsing op de Rav-lijst).

6. De ontwikkelde borgingsmethoden kunnen ook een rol spelen bij de borging van keten- of gebiedsgerichte arrangementen. 


\section{Bronnen}

Berman A., Folman Y.M., Kaim M., Mamen Z., Herz D., Wolfenson A., Graber Y. (1985) Upper critical temperatures and forced ventilation effects for high-yielding dairy cows in a tropical climate. J. Dairy Sci. 68, 488-495.

Brouwer E. (1965). Report of sub-committee on constants and factors. P. 441-443 in Energy Metabolism. EAAP Publ. No. 11. Acad. Press, New York.

Bruggen C. van, A. Bannink, C.M. Groenestein, B.J. de Haan, J.F.M. Huijsmans, H.H. Leusink, S.V. Oude Voshaar, S.M. van der Sluis, G.L. Velthof \& J. Vonk, 2017. Emissies naar lucht uit de landbouw in 2014, Berekeningen met het model NEMA. Wageningen, WOT Natuur \& Milieu, WOttechnical report 90.

Edouard N., Mosquera J, Dooren H.J.C., Mendes L.B., Ogink N.W.M. (2016) Comparison of CO2- and SF6- based tracer gas methods for the estimation of ventilation rates in a naturally ventilated dairy barn. Biosystems Engineering 149, 11-23.

Holster H., M. de Haan, M. Plomp, M. Timmerman , 2015. KringloopWijzer, goed geborgd!? Update van de invoergegevens naar de geactualiseerde versie 2014.06 van de KringloopWijzer, rapport 839, Wageningen UR Livestock Research, Wageningen (in prep).Šebek, L., G. Migchels, C. van Dijk. Het verlagen van de TAN-excretie als maatregel om de ammoniakemissie op het melkveebedrijf te verminderen. Methodiek voor het vaststellen van de TANexcretie: module 'Bedrijfsspecifieke Emissie Ammoniak' (BEA) van de Kringloopwijzer. Wageningen Livestock Research, Rapport 1020.Atrian P. and Shahryar H.A. (2012) Heat stress in dairy cows (a review). Research in Zoology 2(4): 31-37. DOI:10.5923/j.zoology.20120204.03

Johnston J.E., McDowell R.E., Shrode R.R., Legates J.E. (1959) Summer climate and its effect on dairy cattle in the Southern region. In: Southern Cooperative Series Bulletin No. 63.

Kadzere C.T, Murphy M.R., Silanikove N., Maltz E, (2002) Heat stress in lactating dairy cows: a review. Livestock Production Science 77, 59-91.

Luesink H.H., S.M. van der Sluis, G.L. Velthof \& J. Vonk, 2014. Emissies naar lucht uit de landbouw in 2012. Berekeningen van ammoniak, stikstofoxide, lachgas, methaan en fijn stof met het model NEMA. Wot-technical report 3. WOT Natuur \& Milieu, Wageningen UR, Wageningen, april 2014. (http://edepot.wur.nl/299687)

Ni J., Vinckier C., Hendriks J., Coenegrachts J. (1999) Production of carbon dioxide in a fattening pig house under field conditions. II. Release from the manure. Atmospheric Environment 33, 36973703.

Ogink N.W.M., Mosquera J., Calvet S., Zhang G. (2013) Methods for measuring gas emissions from naturally ventilated livestock buildings: Developments over the last decade and perspectives for improvement. Biosystems Engineering, 116 (3), 297-308.

Pedersen S., Blanes-Vidal V., Joergensen H., Chwalibog A., Haeussermann A., Heetkamp M.J.W., Aarnink A.J.A. (2008) Carbon dioxide production in animal houses: a literature review. Agricultural Engineering International: CIGR Ejournal. Vol. X, 1-19.

Wachenfelt E. von, Pedersen S., Gustafsson G. (2001) Release of heat, moisture and carbon dioxide in an aviary system for laying hens. Br Poult Sci. 42(2):171-9. DOI: 10.1080/00071660120048401 


\section{Bijlage 1 Mogelijke weidegangpakketten}

\author{
Emissiereductie door (extra) weidegang \\ Weidegang leidt tot een fors lagere emissie \\ doordat minder mest hoeft te worden uitgereden \\ (emissie-factor $2 \%$ bij weiden versus $19 \%$ bij \\ uitrijden van mest) 2 .
}

De potentiële emissiewinst (uitgedrukt in Kton ammoniak) van weidegang bij verschillende uren weidegang en bij toepassing op een verschillend aantal bedrijven is in nevenstaande tabel weergegeven. Hierbij is zowel het veldeffect (lees minder volume mest dat uitgereden hoeft te worden) als het staleffect meegenomen.

\section{Bestaande weidegangpakketten}

Op dit moment is er slechts één weidegangpakket opgenomen in de Regeling Ammoniak en Veehouderij (Rav), namelijk een pakket met 720 uur weidegang ${ }^{3}$. Voor de borging daarvan geldt de eis dat de melkveehouder dient aan te tonen dat de melk is geleverd aan een zuivelonderneming dit weidegang heeft gecertificeerd.

\section{Mogelijk toekomstige weidegangpakketten} De biologische melkveehouderij heeft eind 2018 besloten te kiezen voor 'Aanvullende Normen'4: het aantal uren weidegang daarin is minimaal 1440 uur, met als aanvullende eis een aanvullende emissiereductie van $10 \%$ op het stalsysteem. Deze variant is nog niet opgenomen in de Rav.

In het verlengde daarvan zijn pakketten denkbaar van 2160, 2880 en > 3500 uur weidegang. Die zouden dan zorgen voor een aanvullende emissiereductie op het stalsysteem van respectievelijk 15, 20 en $25 \%$.

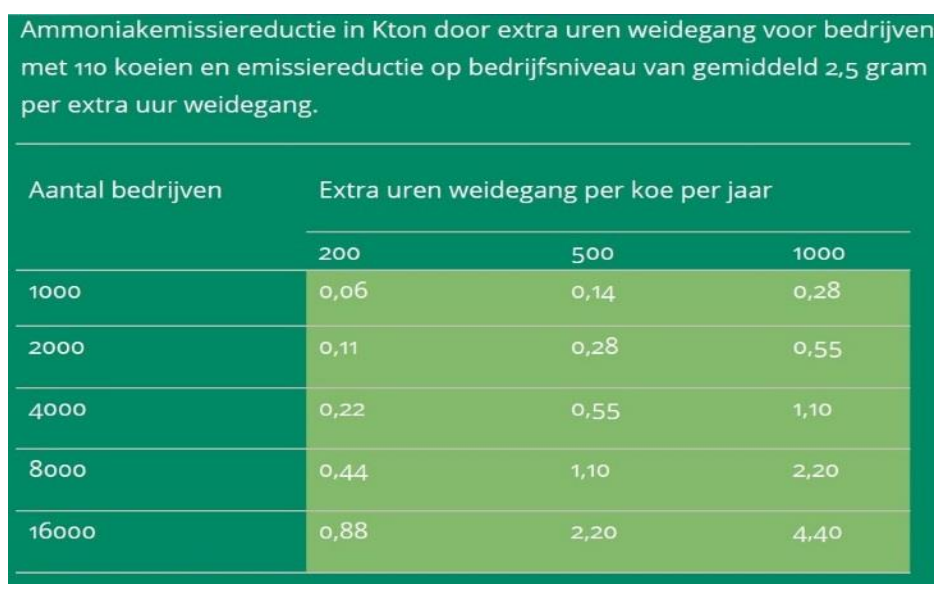

\section{Tabel 1}

Ammoniakemissiereductie van de stal bij conventioneel melken in een

conventioneel melksysteem en bij een toenemend aantal uren weidegang

van de koppel op gangbare en biologische melkveebedrijven.

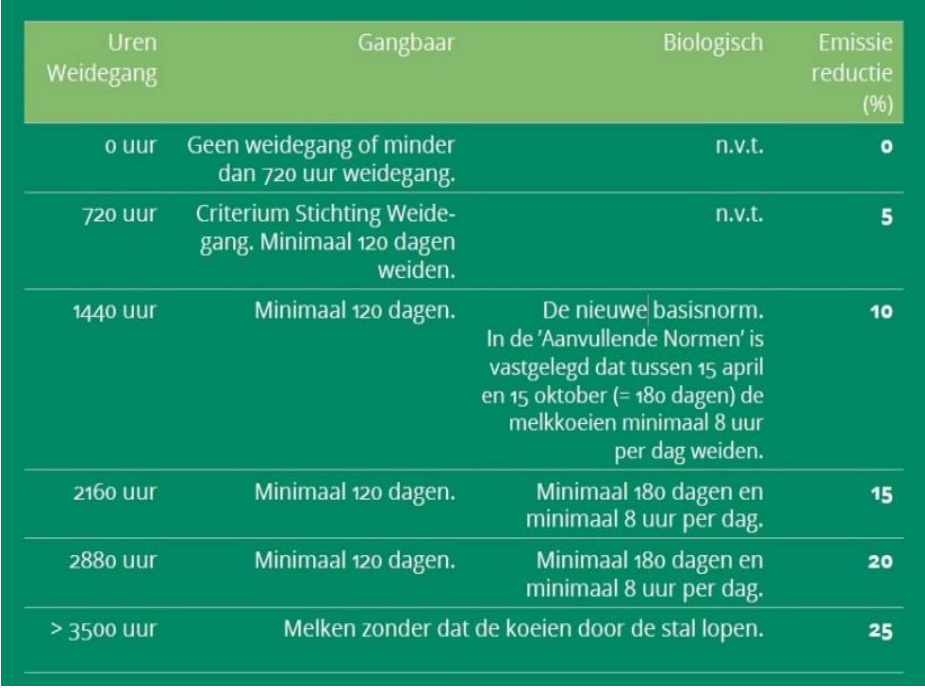

\footnotetext{
2 Uit recent onderzoek van de WUR naar de ammoniakemissie uit een ligboxenstal bij toepassing van weidegang, blijkt dat de afname van de stalemissie door weidegang mogelijk minder groot is dan tot nog toe is verondersteld. Omdat de resultaten van dit onderzoek nog niet zijn gepubliceerd is in de tabellen 1 en 2 uitgegaan van de 'oude' emissiewaarden zoals die in de literatuur worden gehanteerd.

3 Hierbij geldt bovendien een aanvullende emissiereductie van het stalsysteem van $5 \%$.

${ }^{4}$ De melkgevende koeien lopen tussen 15 april en 15 oktober dagelijks minimaal 8 uren in de wei (uitgezonderd extreme weers- en bodemomstandigheden, maar minimaal in deze periode 120 dagen en daarbij 6 uur per dag).
} 
Daarnaast geldt dat op steeds meer melkveebedrijven wordt gemolken met een Automatisch MelksSysteem (AMS). Daarom is er ook gekeken naar het effect van weidegang-pakketten voor bedrijven met een AMS.

Omdat bij een AMS altijd 25\% van de melkkoeien in de stal is, zal de emissiereductie door weidegang kleiner zijn. Dat betekent dat er meer uren weidegang nodig zijn om te komen tot een zelfde reductie als bij een traditioneel melksysteem waarbij alle melkkoeien de stal na het melken verlaten. Dat is weergegeven in bijgaande tabel.

Er zijn vervolgens 3 varianten denkbaar: 960 uur, 1920 uur en 2880 uur weidegang, leidend tot een aanvullende ammoniakemissie reductie van respectievelijk 5, 10 en $15 \%$.

Geen van deze pakketten is momenteel opgenomen in de Rav.

\section{Tabel 2}

Benodigde uren weidegang bij $25 \%$ van de koppel in de stal voor bedrijven met AMS

en een vergelijkbare emissiereductie als bij conventionele melksystemen.

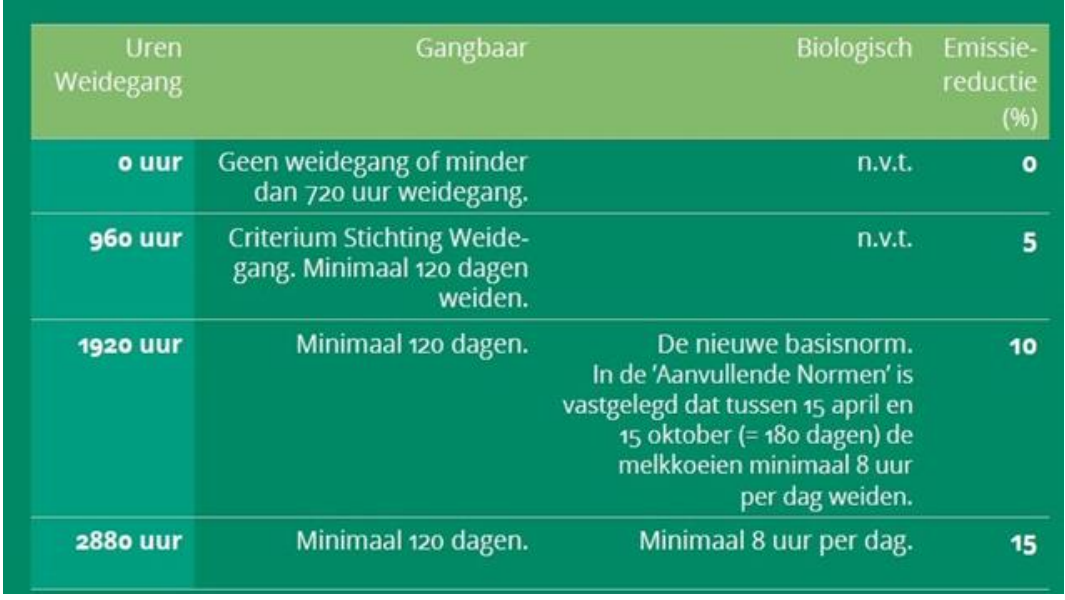




\section{Bijlage 2 Resultaten literatuurstudie naar $\mathrm{CO}_{2}$-uitstoot uit de stal}

\section{CO2 productie in de stal}

- De CO2 in een stal is afkomstig van het metabolisme van de aanwezige dieren en de mest (Edouard et al., 2016) en wordt relatief gemakkelijk door de dieren zelf homogeen over de stal verdeeld waardoor het gemakkelijker mengt met lucht (Edouard et al., 2016).

- De CO2 productie van een dier kan afgeleid worden van z'n energiestofwisseling, welke gerelateerd is aan het voerniveau en de nutriëntensamenstelling van het voer (Brouwer, 1965).

- Pedersen et al. (2008) schrijft dat de CO2 productie van een dier afhangt van de soort, het gewicht en voerniveau en dat dit varieert van ongeveer 0.16 tot $0.21 \mathrm{~m} 3 \mathrm{~h}-1 \mathrm{hpu}-1$. Daarbij geeft hij op basis van resultaten van verschillende onderzoeken een richtlijn voor de totale $\mathrm{CO} 2$ productie van onder andere kalveren en melkkoeien in traditionele stallen (exclusief potstallen). Deze gegevens staan in tabel 3. De berekening van de totale $\mathrm{CO} 2$ productie is gebaseerd op de totale warmteproductie van een dier (hpu) voor onderhoud, melkproductie en dracht bij een 'normale' binnentemperatuur van $20^{\circ} \mathrm{C}$. Daarbij is $1 \mathrm{hpu}=1000 \mathrm{~W}$ (Pedersen at al., 2008; Edouard et al., 2016). Om rekening te houden met de hoeveelheid CO2 die uit mest geproduceerd wordt, wordt een correctie van $+10 \%$ op dierniveau toegepast. Dit percentage geldt voor stallen waarin de mest niet langer dan 3 weken opgeslagen ligt. In stallen waar de mest langer dan 3 weken blijft liggen, kan de $\mathrm{CO} 2$ productie tot 35\% hoger uitvallen door het hogere aandeel uit mest (Ni et al., 1999b; Pedersen et al., 2008).

Tabel 3 Richtlijn voor de totale CO2 productie van kalveren en melkkoeien in traditionele stallen

\begin{tabular}{|c|c|c|}
\hline & $\begin{array}{l}\mathrm{CO}_{2} \text { productie op dierniveau } \\
\left(\mathrm{m}^{3} \mathrm{~h}^{-1} \mathrm{hpu}^{-1}\right)\end{array}$ & $\begin{array}{l}\mathrm{CO}_{2} \text { productie op stalniveau } \\
\left.\left.\left(\mathrm{m}^{3} \mathrm{~h}^{-1} \mathrm{hpu}^{-1}\right)^{*}\right) * *\right)\end{array}$ \\
\hline Kalveren & 0.155 & 0.170 \\
\hline Melkkoeien & 0.180 & 0.200 \\
\hline
\end{tabular}

\section{Dierlijke activiteit en $\mathrm{CO} 2$ productie}

Dierlijke activiteit beïnvloedt de $\mathrm{CO} 2$ productie. Uit een studie bij leghennen bleek dat de nachtelijke CO2 productie 66\% lager lag dan overdag (Wachenfelt et al., 2001; Pedersen et al., 2008). De dierlijke $\mathrm{CO} 2$ productie bij normale boerderij-omstandigheden heeft normaal gesproken een dagvariatie (24-uur) van +/- 20\% (Pedersen et al., 2008). In stallen waar de dieren twee keer per dag gevoerd worden, zijn er twee maxima te zien in dieractiviteit, een in de ochtend en een in de avond. Maar de meeste variatie in $\mathrm{CO} 2$ productieniveau kan benaderd worden met een sinusfunctie (Pedersen et al., 2008).

\section{CO2 productie in relatie tot omgevingstemperatuur}

De lichaamstemperatuur van de koe is een balans tussen warmteproductie en -verlies. Wanneer de omgevingstemperatuur hoger dan ca. $25{ }^{\circ} \mathrm{C}$ is, ervaren koeien hittestress en proberen ze meer warmte te verliezen. De gevolgen van hittestress zijn groter bij hoogproductieve koeien, omdat zij een hogere warmteproductie hebben (Atrian and Shahryar, 2012).

Een van de eerste manieren waarop de koe warmte probeert te verliezen, is door te hijgen, waarbij de ademhaling wordt versneld. Het aantal ademhalingen kan toenemen van $20 / \mathrm{min}$ onder koele omstandigheden tot 100 / min en meer bij temperaturen van $32^{\circ} \mathrm{C}$ en hoger (Johnston et al., 1959; Kadzere et al., 2002). Bij omgevingstemperaturen vanaf $25^{\circ} \mathrm{C}$ steeg de ademhaling naar 50-60 / min 
in studies aan hoogproductieve koeien in een subtropische omgeving (Berman et al., 1985; Kadzere et al., 2002). De excretie van CO2 neemt hierbij fors toe en kan zelfs leiden tot een verstoring van de zuur-base balans (Atrian and Shahryar, 2012). De mogelijkheid om te kunnen koelen via hijgen is mede afhankelijk van de luchtvochtigheid en de wind. Een hoge luchtvochtigheid beperkt namelijk de mogelijkheid om op deze manier te koelen, terwijl wind (luchtbeweging) juist gunstig is voor koeling via evaporatie (Atrian and Shahryar, 2012). 


\section{Bijlage 3 Onderzoek $\mathrm{CO}_{2}$-metingen}

\section{Opzet van de pilot}

Om te kijken of CO2-metingen ook daadwerkelijk een goede indicatie geven van het aantal dieren dat zich (niet) in de stal bevindt, is op twee melkveehouderijbedrijven in Bodegraven en Benschop 2 verschillende gekalibreerde $\mathrm{CO} 2$ sensoren (Vaisala en SensAir) samen op 1 punt op een hoogte van ca. 3 meter opgehangen in de stal, waarbij de sensoren niet rechtstreeks boven de ligboxen opgehangen werden. In Benschop in het gangpad in aanloop naar de melkstal voor alle koeien en voor een deel van de koeien ook op de route vanuit de ligboxen naar de waterbak en krachtvoerbox. In Bodegraven zijn de sensoren rond de voercomputer gehangen in het stalgedeelte voor de waterbak. De krachtvoerboxen en voergang liggen om de hoek en de melkstal ligt aan de andere kant van de stal. Wanneer koeien water willen drinken bevinden ze zich onder de sensoren en wanneer ze willen vreten, zijn er 2 mogelijke routes. Voor een deel van de koeien is de route langs de waterbak het meest logisch, omdat dit de kortste route is vanuit de ligboxen. De aanwezige droge koeien (8) kunnen geen invloed op de sensormetingen hebben, aangezien de ruimte daarvoor aan de andere kant van de stal ligt.

Het ene melkveebedrijf (Benschop) hanteert all in- all out voor beweiding en het andere bedrijf (Bodegraven) heeft vrij koeverkeer en is vanaf 20 mei 2018 gestart met het DZK-borgingssysteem voor weidegang. De koeien kregen in Bodegraven vanaf 7 juni dag en nacht weidegang.

De metingen zijn begonnen op respectievelijk 5 en 6 juni 2018. Aan de melkveehouders werd gevraagd gegevens te noteren, voor zover nodig, wat betreft de tijdstippen waarop de koeien naar buiten en binnen gingen, het aantal dieren dat bij weidegang in de stal achterbleef (zoals droge koeien, jongvee), openen en sluiten van stalgordijnen en de weersomstandigheden.

Elke minuut werd een $\mathrm{CO} 2$ meting gedaan, die werd opgeslagen met behulp van dataloggers (Koendersboxen). De data werden op beide bedrijven uitgelezen op 22 juni 2018. Van het bedrijf met vrij koeverkeer werd de informatie over de koebewegingen door de melkveehouder uit Dairyplan (GEA) gehaald en digitaal aangeleverd. De data over de weersomstandigheden ten tijde van de periode waarin gemeten werd, zijn afkomstig van de dichtstbijzijnde KNMI WOW weerstations nr. 19 en 21. Het weerstation nr. 19 in Bodegraven en nr. 21 in IJsselsteijn. Nr. 19 ligt het dichtst bij het bedrijf in Bodegraven en nr. 21 het dichtst bij het bedrijf in Benschop.

\section{Resultaten}

Het bedrijf in Benschop heeft 85 melkkoeien, 5 droge koeien, 25 stuks jongvee (0-1 jr.) en 25 stuks jongvee (1-2 jr.). De huisvesting is een traditionele ligboxenstal met roostervloeren. De schatting van de hoeveelheid mest in de stal is $40 \%$ bij aanvang van de metingen. De geografische positie is OostWest. In tabel 1 staat van de data die verderop in de tekst nader toegelicht worden de informatie over de tijden waarop de melkkoeien naar buiten en weer naar binnen gingen en het aantal dieren dat achterbleef in de stal.

Tabel 4 Aantal dieren dat in de stal achterbleef gedurende de weidegangperiode. Weergegeven voor de data waarvan de grafieken toegelicht worden in deze notitie.

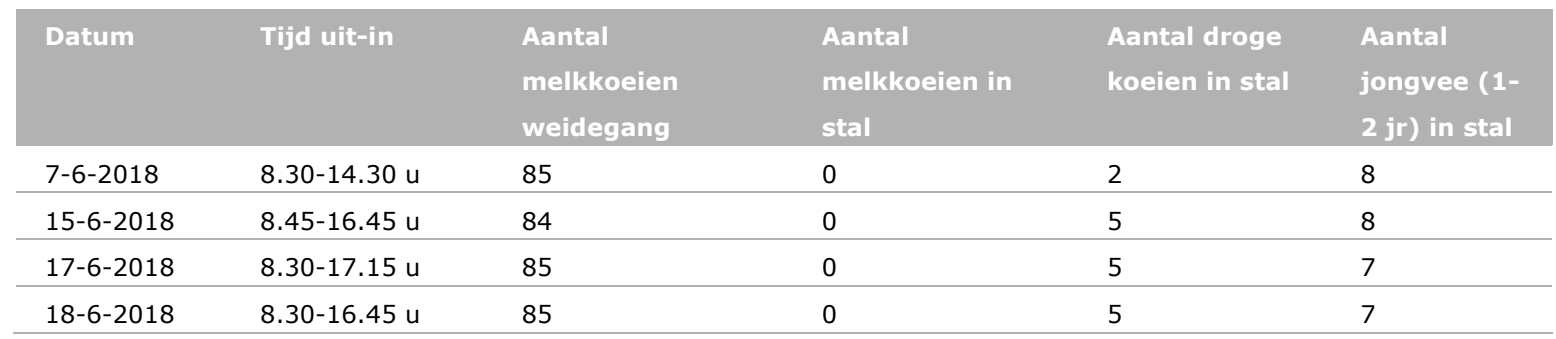


In Bodegraven zijn 70 melkkoeien, 8 droge koeien, 14 stuks jongvee (0-1 jr.) en 14 stuks jongvee (12 jr.) aanwezig op het bedrijf. Het staltype is $3+1$ met een emissie arme roostervloer. De schatting van de hoeveelheid mest is $20 \%$ van de maximale capaciteit bij aanvang van de proef. De geografische positie van de stal is NW-ZO. Aanvankelijk bleven er 4 en later 7 melkkoeien achter in de stal.

\section{Data CO2 metingen}

Aan de metingen op het bedrijf in Benschop is duidelijk onderscheid te zien in de hoeveelheid $\mathrm{CO} 2$ (ppm) wanneer de koeien allemaal binnen of buiten zijn. Bij vrij koeverkeer (bedrijf Bodegraven) zijn de patronen minder duidelijk. Ter illustratie zijn de figuren 1 en 2 toegevoegd. De koeien gingen in Benschop om ong. 8.30 u naar buiten en om ong. 14.30 uur weer naar binnen vanwege de warmte. De hoogst gemeten temperatuur in IJsselsteijn was die dag $30.6{ }^{\circ} \mathrm{C}$ (17.20 u) en in Bodegraven 29.6 ${ }^{\circ} \mathrm{C}(17.00 \mathrm{u})$.

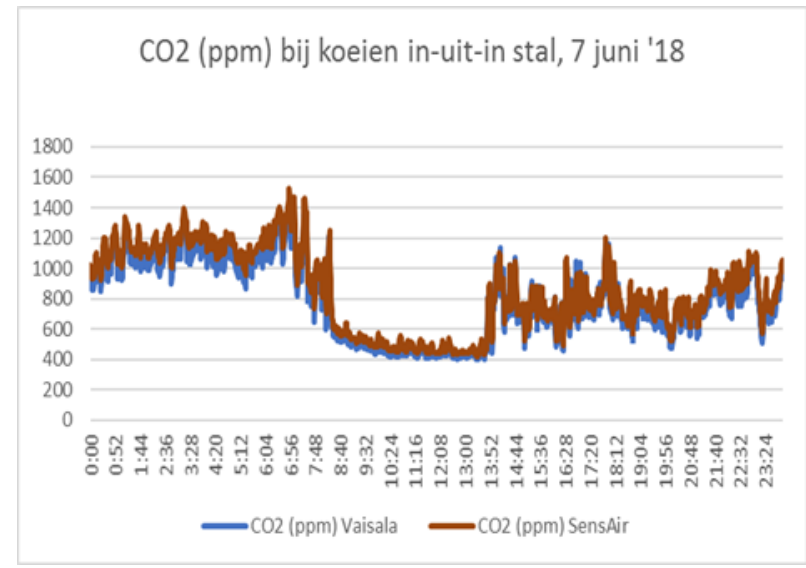

Figuur 1

(Benschop)

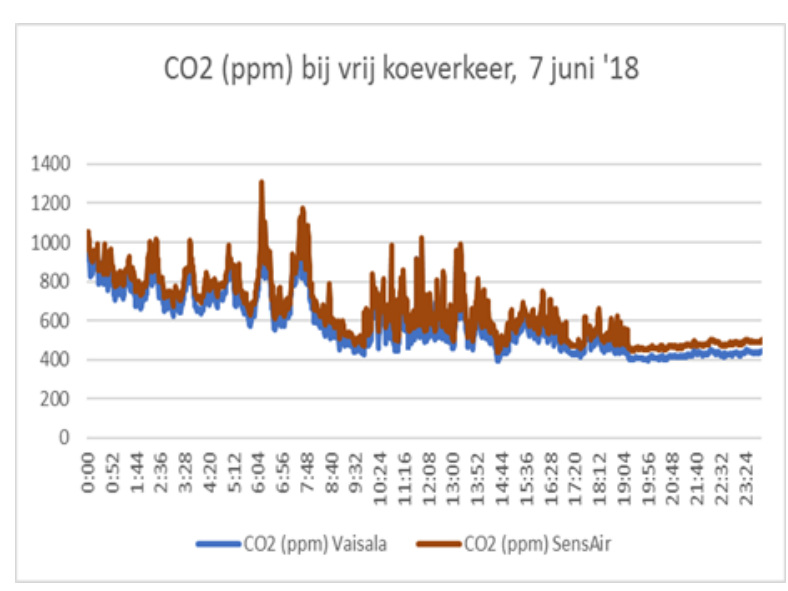

Figuur 2 (Bodegraven)

Het CO2 gehalte zakt telkens terug naar ong. 400 ppm wanneer de koeien allemaal naar buiten zijn. Alhoewel het verschil tussen binnen en buiten duidelijker is op het bedrijf met all-in all-out, lag de ondergrens op beide bedrijven op ong. 400 ppm op alle dagen dat gemeten werd. Ter illustratie zijn de figuren 3 en 4 toegevoegd. De koeien gingen in Benschop om ong. 8.45 u naar buiten en om ong. 16.45 uur weer naar binnen vanwege de warmte. De hoogst gemeten temperatuur in IJsselsteijn was die dag $27.2{ }^{\circ} \mathrm{C}$ (om $16.10 \mathrm{u}$ ) en in Bodegraven $24.9{ }^{\circ} \mathrm{C}(15.50 \mathrm{u}$ ).

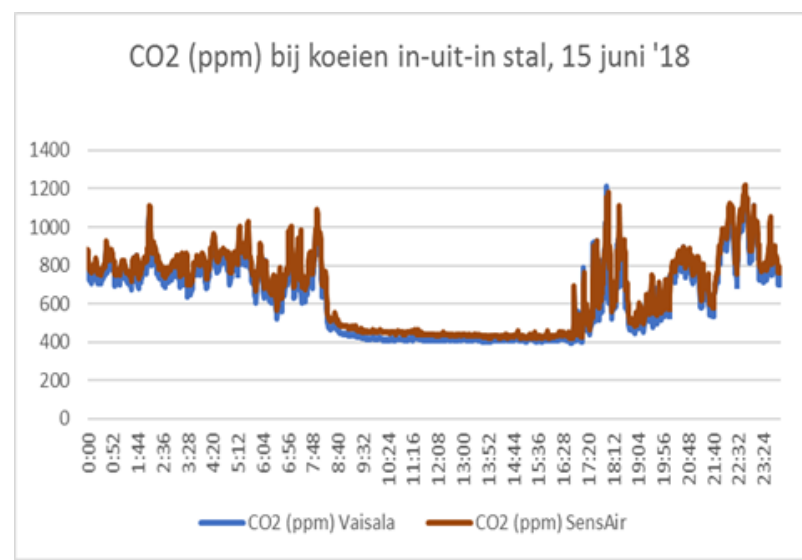

Figuur 3 (Benschop)

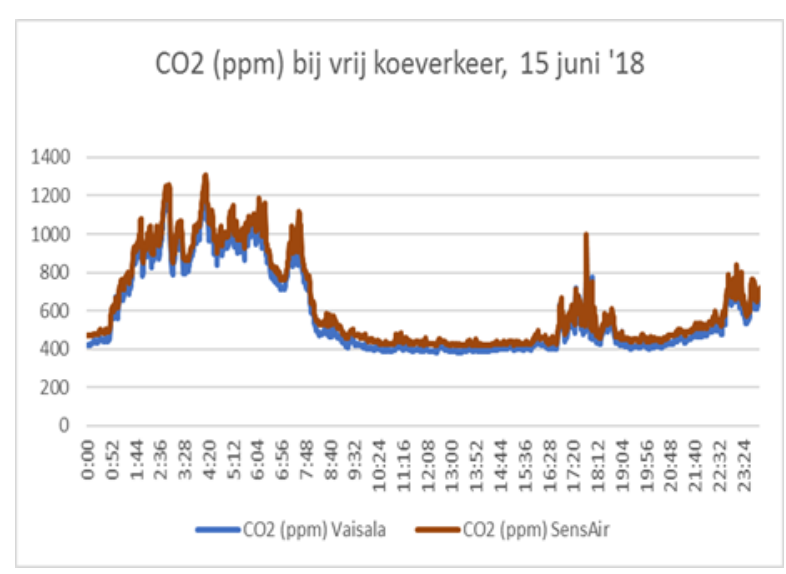

Figuur 4 (Bodegraven) 


\section{Weersomstandigheden}

Het verschil in $\mathrm{CO} 2$ tussen binnen en buiten is gekoppeld aan de temperatuur. Bij hogere temperaturen is de $\mathrm{CO} 2$ productie hoger waardoor het verschil tussen alle koeien in of uit de stal groter en duidelijker is. Gedurende de meetperiode was de buitentemperatuur een paar dagen een stuk lager waardoor het onderscheid tussen buiten en binnen veel kleiner werd. Vraag is dan ook of bij een nog lagere temperatuur het onderscheid tussen binnen en buiten nog te maken is. Ter illustratie zijn de figuren 5 en 6 toegevoegd van de dag met de laagst gemeten maximale temperatuur gedurende de meetperiode van 6 tot 22 juni: 17 juni. Op die dag was de hoogst gemeten temperatuur in IJsselsteijn $19.3^{\circ} \mathrm{C}\left(14.30 \mathrm{u}\right.$ ) en in Bodegraven $19.4{ }^{\circ} \mathrm{C}(14.30 \mathrm{u})$. De koeien gingen in Benschop om ong. $8.30 \mathrm{u}$ naar buiten en om ong. 17.15 uur weer naar binnen.

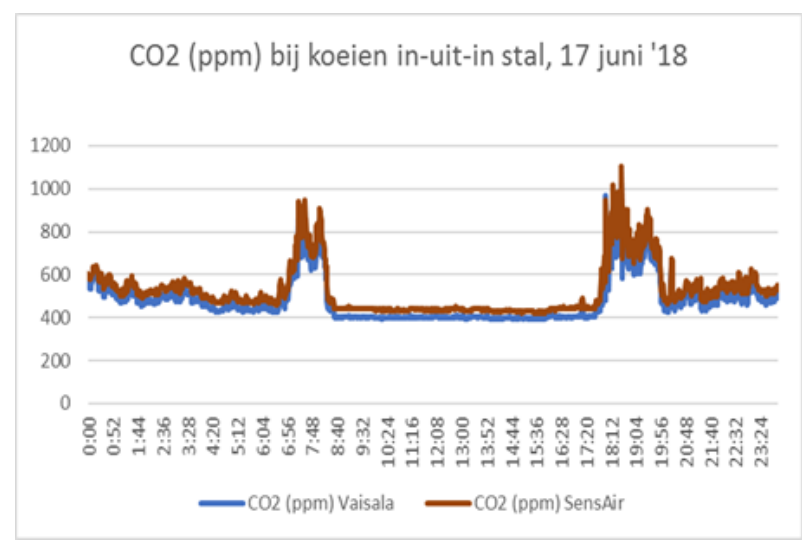

Figuur 5 (Benschop)

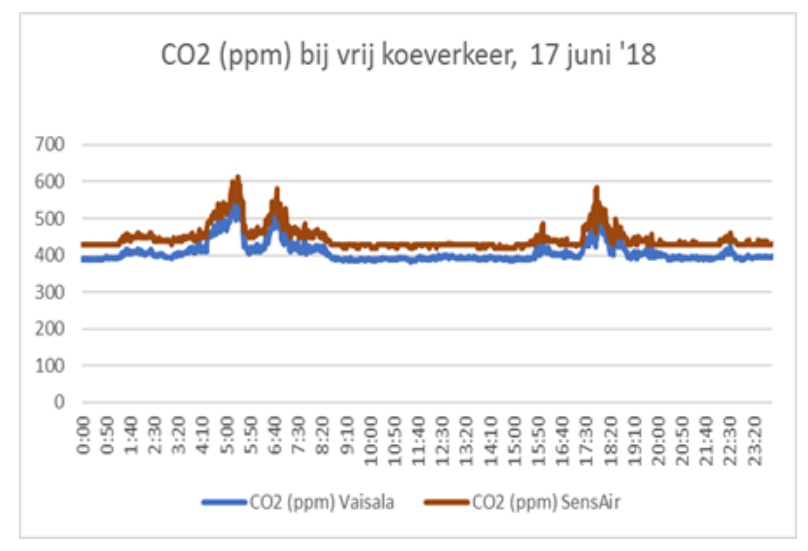

Figuur 6 (Bodegraven)

In tabel 2 is per datum waarvan een grafiek getoond is in deze notitie een overzicht te zien van de gemiddelde weersomstandigheden op de momenten dat de koeien buiten en in de stal waren op het bedrijf in Benschop. Omdat op het bedrijf in Bodegraven vrij koeverkeer is en er geen sprake is van all-in all-out, kunnen de weersomstandigheden niet op dezelfde wijze gepresenteerd worden.

Tabel 5 Per dag de gemiddelde weersomstandigheden bij koeien in en uit de stal op bedrijf in Benschop op basis van meetgegevens WOW station nr. 21.

\begin{tabular}{|c|c|c|c|c|c|c|}
\hline Datum & $\begin{array}{l}\text { Koe in } \\
\text { of uit } \\
\text { stal }\end{array}$ & $\begin{array}{l}\text { Gem. } \\
\text { buitentemp } \\
\left({ }^{\circ} \mathrm{C}\right)\end{array}$ & $\begin{array}{l}\text { Gem. } \\
\text { wind } \\
\text { snelheid }\end{array}$ & $\begin{array}{l}\text { Gem. wind } \\
\text { richting }\left({ }^{\circ}\right)\end{array}$ & $\begin{array}{l}\text { Gem. relatieve } \\
\text { luchtvochtigheid } \\
\text { buiten }(\%)\end{array}$ & $\begin{array}{l}\text { Gem. } \\
\text { neerslag } \\
\text { ( } \mathrm{mm} / \text { uur) }\end{array}$ \\
\hline $7-6-2018$ & uit & 26 & - & - & 55 & 0 \\
\hline $7-6-2018$ & in & 22 & - & - & 66 & 0 \\
\hline $15-6-2018$ & uit & 23 & 1 & 210 & 54 & 0 \\
\hline $15-6-2018$ & in & 19 & 0 & 174 & 67 & 0 \\
\hline $17-6-2018$ & uit & 16 & 1 & 242 & 68 & 0 \\
\hline $17-6-2018$ & in & 15 & 1 & 250 & 75 & 0 \\
\hline $18-6-2018$ & uit & 18 & 2 & 247 & 79 & 0 \\
\hline $18-6-2018$ & in & 16 & 1 & 249 & 74 & 0 \\
\hline
\end{tabular}

\section{Locatie van de sensoren}

Er zijn pieken en dalen te zien in de CO2 meting die qua tijdstip te koppelen zijn aan het moment van melken en aan het voerhek staan (zie figuren 7 en 8). Momenten waarop de activiteit toeneemt rondom bepaalde plekken en de sensoren mogelijk gunstig dan wel ongunstig hangen. Alhoewel bij het plaatsen van de sensoren goed is nagedacht over de locatie, is dit toch is iets waar nog beter naar gekeken moet worden. Misschien is dit ook te ondervangen door in plaats van op 1 plek een paar sensoren op verschillende locaties te plaatsen. Nadeel is dat hierdoor de kosten toenemen. 


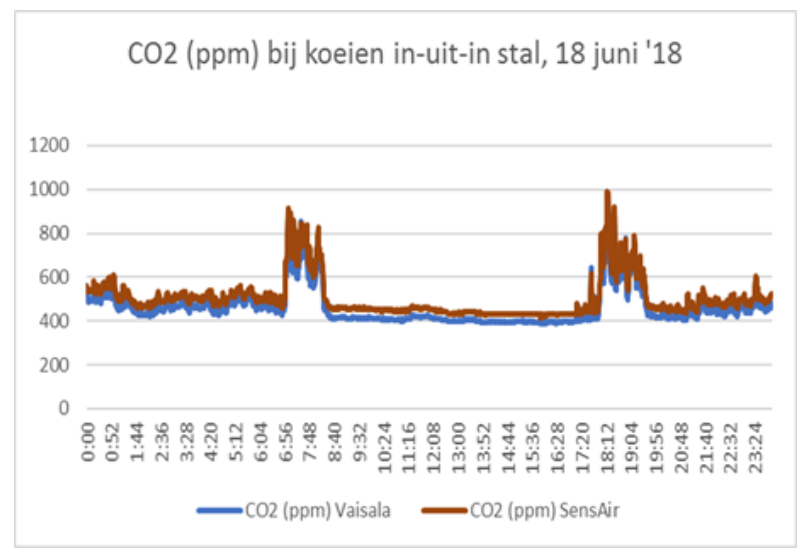

Figuur $7 \quad$ (Benschop)
$\mathrm{CO2}$ (ppm) bij vrij koeverkeer, 18 juni '18

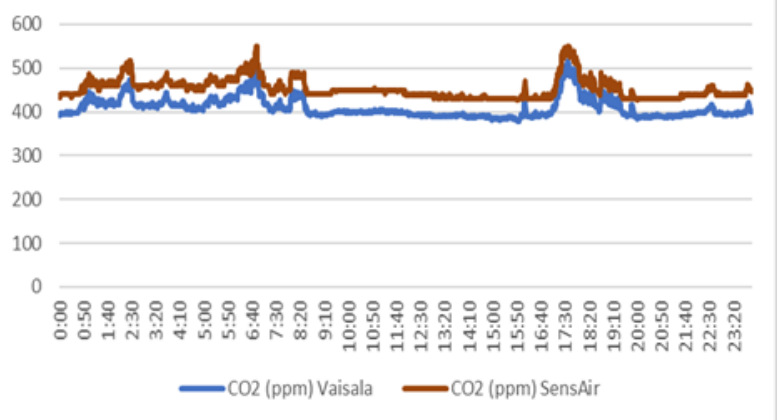

Figuur 8 (Bodegraven)

\section{Onderscheid Vaisala en SensAir CO2 meter}

Zowel de Vaisala als SensAir sensoren laten de patronen zien, waarbij de Vaisala iets lagere $\mathrm{CO} 2$ waarden meet dan de SensAir sensoren. Zie bovenstaande figuren 6 en 8 (met een y-as verdeling van 100 ppm). De Vaisala sensor is in aanschaf duurder dan de SensAir.

\section{Bijhouden gegevens door de melkveehouders}

Op het bedrijf in Benschop werden de gegevens zoals gevraagd genoteerd. De stalgordijnen waren continu open. Van het bedrijf in Bodegraven kon de informatie over de stalgordijnen niet verkregen worden, omdat de daarvoor benodigde sd-kaart ontbrak en hiervoor bovendien een apart software programma geschreven moet worden om de juiste gegevens op te kunnen slaan. De melkveehouder heeft de bediening van stalgordijnen gedurende de meetperiode niet van automatisch naar handmatig over gezet. Bij wisselvallig weer zouden, om te voorkomen dat de boxen in de stal nat worden, de gordijnen voor elke regenbui handmatig gesloten moeten worden. Deze weersomstandigheden hebben zich inderdaad een paar dagen voorgedaan.

\section{Weidegang en CO2: Discussie en conclusies}

\section{Data CO2 metingen}

Uit de pilot blijkt dat met $\mathrm{CO} 2$ meting op een bedrijf met all in-all out verschil is aan te tonen tussen wanneer de koeien in de stal of buiten zijn. Op het bedrijf met vrij koeverkeer is dit lastiger aan te tonen en helemaal wanneer de koeien dicht bij huis weidegang krijgen, vanwege het grotere aantal koebewegingen dat dan mogelijk is. Hiervoor zullen apart rekenregels ontwikkeld moeten worden die de data van de koebewegingen omzetten naar het aantal koeien in de stal en vervolgens koppelen aan de $\mathrm{CO} 2$ metingen.

De hoeveelheid CO2 werd elke minuut gemeten. Voor het onderscheid tussen of alle koeien in de stal of buiten zijn, lijkt dit niet nodig. Wanneer slechts 1 keer per 10 minuten een waarde gemeten wordt, is het mogelijk om voor een langere periode data op te slaan.

\section{Invloed weersomstandigheden op $\mathrm{CO} 2$ metingen}

Een toename van de omgevingstemperatuur leidt tot een toename van het aantal ademhalingen en $\mathrm{CO} 2$ productie. Door de temperaturen die tijdens de pilotperiode gemeten werden, geven de $\mathrm{CO} 2$ metingen onvoldoende uitsluitsel of $\mathrm{CO} 2$ meting een alternatieve borgingsmethode voor weidegang kan zijn. Voor de volledigheid zou het goed zijn om ook aan het eind (of helemaal aan het begin) van de weideperiode, wanneer de temperatuur wat lager is, te onderzoeken of met $\mathrm{CO} 2$ meting in de stal nog steeds het verschil tussen koeien in de stal of in de wei aangetoond kan worden. Dit geldt ook voor de overige weersomstandigheden. 
Invloed locatie sensoren en dieractiviteit op $\mathrm{CO} 2$ metingen

In de resultaten werd genoemd dat er pieken en dalen te zien in de $\mathrm{CO} 2$ meting die qua tijdstip te koppelen zijn aan het moment van melken en aan het voerhek staan (zie figuren 7 en 8). Momenten waarop de activiteit toeneemt rondom bepaalde plekken en de sensoren mogelijk gunstig danwel ongunstig hangen. Pederson et al. (2008) beschreef echter ook dat in stallen waar de dieren twee keer per dag gevoerd worden er twee maxima te zien zijn in $\mathrm{CO} 2$ productie als gevolg van dieractiviteit, een in de ochtend en een in de avond.

Alhoewel bij het plaatsen van de sensoren goed is nagedacht over de locatie, is dit toch is iets waar nog beter naar gekeken moet worden. Misschien is dit ook te ondervangen door in plaats van 1 sensor een paar sensoren op verschillende locaties te plaatsen. Uit oogpunt van de kosten die dit met zich meebrengt, is het plaatsen van meer dan 1 sensor waarschijnlijk niet wenselijk, aangezien het doel is om een goedkoper alternatief voor het DZK-borgingssysteem voor weidegang te vinden.

Conclusie: Met CO2 metingen op 1 punt in de stal is vast te stellen of de koeien in de stal of buiten zijn (in de wei lopen). De patronen van $\mathrm{CO} 2$ concentraties veranderen duidelijk.

\section{Aanbevelingen}

- $\quad$ Tweede keer metingen doen bij een periode van extreem warm weer om te zien wat dan het effect op de hoeveelheid $\mathrm{CO} 2$ in de stal is. Afspraak is dat de gegevens hiervoor uitgelezen worden op 1 augustus 2018.

- $\quad$ Derde keer metingen doen wanneer de temperatuur verder gezakt is. Het voorstel is om dit aan het einde van het weideseizoen (eind september/ begin oktober) te doen om te zien wat dan de verschillen in $\mathrm{CO} 2$ zijn. Mogelijk zijn de verdere weersomstandigheden dan ook anders (bijv. heel harde wind, regen) en daardoor meer van invloed.

- Opnieuw nadenken over de locatie waar de sensoren geplaatst worden en het aantal sensoren. Daarbij rekening houden met de kosten.

- Bepalen hoe vaak er een meting gedaan moet worden. Er werd in deze proef elke minuut gemeten, terwijl dit waarschijnlijk naar 1 keer per 10 minuten zou kunnen. Dit bespaart opslagcapaciteit.

- Wanneer uit de derde serie metingen blijkt dat met CO2 metingen ook bij lagere temperaturen en 'all in - all out' er verschil tussen weidegang en in de stal staan gevonden wordt, dan moet vervolgens de dataverzending geregeld worden.

\section{Betrokkenen bij $\mathrm{CO} 2$ meting als alternatieve borgingsmethode voor weidegang}

Reina Ferwerda-van Zonneveld, Gerard Migchels, Nico Ogink, Hendrik Jan van Dooren, Johan

Ploegaert, Guus Nijeboer (allen WLR) en Stefan Breukel en Jacob van Vliet (beiden LNV), Auke Snijder (De Zuivelmakers) 


\section{Bijlage 4 Afleiden TAN-productie}

Gebruik de BEA rekenmethodiek voor de TAN-productie om de gerealiseerde TAN-productie te berekenen.

Corrigeer de ammoniakemissie volgens de Rav op basis van het verschil in TAN-productie tussen de bedrijfsspecifiek gerealiseerde TAN productie en de Standaard landelijk gemiddelde TAN productie.

1. Afleiden standaard TAN-productie.

- Doel: berekenen van de TAN-productie in het standaard Rav staltype A1.100 met drijfmest en permanent opstallen.

- Rav geeft voor dit staltype een emissie van 13,0 kg NH3 per dierplaats per jaar.

- $\quad$ NEMA geeft voor dit staltype het percentage TAN die als NH3-N vervluchtigt ( $12,7 \%)$.

- $\quad$ Met die 13,0 kg ammoniak per jaar en EF = 12,7\% wordt gerekend:

- De Rav lijst geeft voor de standaard stal een emissie van 13,0 kg NH3 .

- $13,0 \mathrm{~kg} \mathrm{NH} 3$ is gelijk aan $10,7 \mathrm{~kg} \mathrm{NH3}-\mathrm{N}$. Dat is weer gelijk aan $12,7 \%$ van TAN.

- $1 \%$ TAN is dus $10,7 / 12,7=0,843 \mathrm{~kg} \mathrm{~N}$ en $100 \%$ TAN $=84,3 \mathrm{~kg} \mathrm{~N}$

- $\quad$ De standaard TAN-productie is $84,3 \mathrm{~kg} \mathrm{~N}$ per dierplaats per jaar.

2. Berekenen $\mathrm{NH} 3$ emissie (kg per dierplaats per jaar) na voer- en managementmaatregelen via corrigeren naar de gerealiseerde TAN:

- $\quad$ Doel: berekenen van een gecorrigeerde Rav emissiefactor in kg NH3 per dierplaats per jaar.

- $\quad$ De Rav standaardstal geeft 13,0 kg NH3 bij 84,3 kg TAN.

- $\quad$ Stel dat de BEA berekent dat er niet $84,3 \mathrm{~kg}$ maar $72,5 \mathrm{~kg}$ TAN per dierplaats per jaar is uitgescheiden (gerealiseerde TAN $=72,5 \mathrm{~kg}$ ).

- $\quad$ Omgerekend is de ammoniakemissie $13,0 \times(72,5 / 84,3)=13,0 \times 0,86=11,18 \mathrm{~kg} \mathrm{NH} 3$ per dierplaats per jaar. De door BEA berekende gecorrigeerde Rav emissie is dan 11,2 kg NH3 per dierplaats per jaar, offwel een reductie van 1,8 kg NH3 per dierplaats.

3. NH3 emissie voor andere Rav staltypes (niet A1.100)

- Doel: Idem als bij 2, maar nu voor andere staltypes

- $\quad$ De berekening is identiek aan 1 en 2, maar start niet met 13,0 kg NH3 maar met de NH3emissie voor het betreffende staltype volgens de Rav lijst.

- $\quad$ Stel staltype Ax is A1.26. Volgens de Rav lijst heeft die stal:

- een emissie van 9,6 kg NH3 per dierplaats per jaar bij de standaard TAN-productie van $84,3 \mathrm{~kg} /$ dierplaats/jaar.

- Door (voer)management reduceert de TAN-productie van de standaard 84,3 kg naar gerealiseerd van 72,5 kg per dierplaats per jaar (gerealiseerde TAN zoals vastgesteld via BEA).

- $\quad$ De door BEA berekende gecorrigeerde ammoniakemissie is dan 9,6 $\times(72,5 / 84,3)=9,6 \times$ $0,86=8,3 \mathrm{~kg} \mathrm{NH} 3$ per dierplaats per jaar, ofwel een reductie van $1,3 \mathrm{~kg} \mathrm{NH} 3$ per dierplaats.

$\mathrm{Nb} 1$ In bovenstaand voorbeeld wordt in beide staltypen de TAN-productie via voermanagement evenveel verlaagd (in $\mathrm{kg}$ ). Echter, omdat het om een procentuele reductie van de vervluchtiging van TAN gaat, is voor het standaard staltype A1.100 de absolute reductie in ammoniakemissie (in $\mathrm{kg}$ ) groter dan voor het emissiearmere staltype A1.26.

4. Voorbeeldberekening

De standaard TAN-productie (op basis NEMA) is door voer- en managementmaatregelen te verkleinen. Volgens van Bruggen e.a. is, binnen de normale in de Nederlandse praktijk voorkomende variatie in TAN-productie en ammoniakemissie, de emissiefactor voor TAN constant. Ofwel niet afhankelijk van het TAN-productieniveau en dus geeft $\mathrm{x} \%$ minder TAN-productie ook $\mathrm{x} \%$ minder ammoniakemissie. 
Het reductiepercentage van de maatregel 'Voer- en managementmaatregel via de BEA' varieert afhankelijk van de gekozen mix aan maatregelen. Het reductiepercentage is dan ook afhankelijk van de gerealiseerde TAN-productie en kan variëren tussen de 0 en meer dan $50 \%$. Zie onderstaand (tabel 3 ) een voorbeeld met een gerealiseerde TAN-productie die $10 \%$ lager is dan de standaard TANproductie.

Tabel 6 Milieuvergunde situatie met bijbehorende ammoniakemissie.

\begin{tabular}{|c|c|c|c|c|c|}
\hline Stal & Diersoort & Aantal dieren & Rav-code & $\begin{array}{l}\text { Emissie-factor } \\
(\mathrm{kg} \mathrm{NH} / \mathrm{jr})\end{array}$ & $\begin{array}{l}\text { Emissie in }(\mathrm{kg} \\
\left.\mathrm{NH}_{3} / \mathrm{jr}\right)\end{array}$ \\
\hline \multirow[t]{2}{*}{$\begin{array}{l}\text { Ligboxen- } \\
\text { stal }\end{array}$} & $\begin{array}{l}\text { Melk- en kalf-koeien } \\
>\text { dan } 2 \text { jaar }\end{array}$ & 150 & A1.100.1 & 9,5 & 1425,0 \\
\hline & Vrouwelijk jongvee & 125 & A3 & 3,9 & 487,5 \\
\hline Totaal & & & & & 1912,5 \\
\hline
\end{tabular}

Tabel 6 concretiseert dat aan de hand van een verleende vergunning voor staltype A1.100 met beperkt weiden en drijfmest (uit een gangbare beschikking). Als uit de BEA blijkt dat door voer- en management maatregelen de gerealiseerde TAN-productie $10 \%$ lager is dan de standaard TANproductie, dan zal de ammoniakemissie uit de ligboxenstal ook $10 \%$ lager zijn. En dan kunnen er bij een gelijkblijvende totale ammoniakemissie (1912,5 kg/jaar) 15 koeien en 12,5 stuks extra jongvee gehouden worden (zie tabel 7).

Tabel 7 Fictieve aanpassing van de milieuvergunde situatie met bijbehorende ammoniakemissie bij realisatie van $10 \%$ reductie in TAN-productie via voer- en management maatregelen.

\begin{tabular}{|c|c|c|c|c|c|c|}
\hline Stal & Diersoort & $\begin{array}{l}\text { Aantal } \\
\text { dieren }\end{array}$ & Rav-code & $\begin{array}{l}\text { Emissie- } \\
\text { factor } \\
(\mathrm{kg} \mathrm{NH} / \mathrm{jr} .)\end{array}$ & $\begin{array}{l}\text { Emissie factor } \\
\text { incl. } 10 \% \text { voer- } \\
\text { en management } \\
\text { maatregelen }\end{array}$ & $\begin{array}{l}\text { Emissie in ( } \mathrm{kg} \\
\left.\mathrm{NH}_{3} / \mathrm{jr} .\right)\end{array}$ \\
\hline \multirow[t]{2}{*}{$\begin{array}{l}\text { Ligboxen- } \\
\text { stal }\end{array}$} & $\begin{array}{l}\text { Melk- en kalfkoeien } \\
\text { ouder dan } 2 \text { jaar }\end{array}$ & 150 & $\mathrm{~A} 1.100 .1$ & 9,5 & 8,55 & 1282,5 \\
\hline & Milieuwinst $(10 \%)$ & & & & & 191,2 \\
\hline Totaal & & & & & & $1.912,5$ \\
\hline
\end{tabular}




\section{Bijlage 5 Prestatiebeschrijving uitrijden van voldoende verdunde mest met een sleepvoet}

De prestatiekenmerken hebben betrekking op het uitrijden van verdunde mest met een sleepvoet. Kern daarbij is het waarborgen dat:

1. de mest voldoende is verdund met water;

2. controle plaats kan vinden op dit verdunnen via het vastleggen en versturen van gegevens (volumes en/of verdunningsverhouding, locatie, tijd)

De combinatie van voorzieningen om bovenstaande mogelijk te maken worden geduid in onderstaande als 'mestverdunning/datalog/GPS apparatuur' .

$1 \quad$ Uiterlijke aanduidingen mestverdunning/datalog/GPS apparatuur

1.1 De mestverdunning/datalog/GPS apparatuur is zichtbaar voorzien van typeaanduiding, een versienummer, een uniek serienummer en een identificatie van de fabrikant.

1.2 Indien de mestverdunning/datalog/GPS apparatuur uit verschillende onderdelen bestaat is ieder te onderscheiden onderdeel zichtbaar voorzien van de in onderdeel 1.1 genoemde kenmerken.

1.3 De mestverdunning/datalog/GPS apparatuur beschikt over een voorziening waarmee het unieke serienummer automatisch wordt vastgelegd en aan elk elektronisch databericht wordt meegegeven.

2 Vastleggen en versturen KvK nummer grondgebruiker

2.1 De mestverdunning/datalog/GPS apparatuur beschikt over een voorziening waarmee het Kvk nummer van de grondgebruiker - waarvoor de verdunde mest wordt uitgereden - wordt vastgelegd en aan elk elektronisch databericht wordt meegegeven.

3 Koppeling mestverdunning/datalog/GPS apparatuur aan de giertank of sleepslang

3.1 De satellietvolgapparatuur is verbonden aan de giertank met sleepvoet. En bij toepassing met sleepslang met sleepvoet (navelstreng) is de satellietvolgapparatuur verbonden met zowel de sleepslang met sleepvoet (navelstreng) als de pomp/verdunner.

3.2 De sensoren die vaststellen of de mest voldoende is verdund en/of sensoren die vaststellen of er geen gier wordt toegevoegd als verdunningsmiddel zijn onderling als een module digitaal en/of fysiek aan elkaar verbonden. Zodat het functioneert als 1 samenhangend systeem.

$4 \quad$ Automatische positiebepaling

4.1 De mestverdunning/datalog/GPS apparatuur beschikt over een voorziening, waarmee direct na het starten van het verdunnen en of uitrijden van de verdunde mest de door de satellietvolgapparatuur gegenereerde gegevens inzake:

- de positie van de giertank met sleepvoet of de uiteinde van de sleepslang met sleepvoet (navelstreng).

- de positie van de pomp/verdunner bij een sleepslang (navelstreng)

- $\quad$ alsmede de datum en het tijdstip, waarop de positiegegevens zijn bepaald voortdurend en automatisch worden vastgelegd 
5.1 De mestverdunning/datalog/GPS apparatuur beschikt over een voorziening, waarmee een voldoende mate van verdunning is vast te stellen c.q. te monitoren. Voldoende mate van verdunning is een garantie van minimaal $0.5 \mathrm{~m} 3$ water per $1 \mathrm{~m} 3$ mest.

5.2 De mestverdunning/datalog/GPS apparatuur beschikt over een voorziening waarmee is vast te stellen dat het verdunnen met water plaatsvindt en niet door gier.

5.3 De mestverdunning/datalog/GPS apparatuur geeft de mate van verdunning weer in de ratio $\mathrm{m} 3$ water per $\mathrm{m} 3$ mest. In dit geval minimaal 0.5 .

6 Opslag van gegevens van de mestverdunning/datalog/GPS apparatuur

6.1 De door de mestverdunning/datalog/GPS apparatuur geregistreerde gegevens worden ten minste 1 uur in deze apparatuur vastgelegd.

$7 \quad$ Versturen van de mestverdunningsgegevens

7.1 De mestverdunning/datalog/GPS apparatuur beschikt over een voorziening, waarmee zowel tijdens het verdunnen als het mest uitrijden automatisch databerichten naar een door de agrarische sector beheerde centrale database verstuurd onmiddellijk nadat de desbetreffende gegevens door de mestverdunning/datalog/GPS apparatuur zijn geregistreerd. De NVWA kan de betreffende databerichten in deze centrale database raadplegen.

7.2 Het eerste databericht is een beginmelding. Minimaal elke 10 minuten wordt er een update bericht verstuurd. Het laatste bericht is een eindmelding.

7.3 Elk tijdens het verdunnen en/of mest uitrijden verstuurde databericht bevat de volgende gegevens:

- Het KvK nummer van de grondgebruiker

- $\quad$ Een code waarmee wordt aangegeven of het een beginmelding, een update bericht of eindmelding betreft

- Het serienummer van de mestverdunning/datalog/GPS apparatuur

- De door de satellietvolgapparatuur gegenereerde gegevens, die zijn vastgelegd direct na het starten van het verdunnen/mestuitrijden.

- $\quad$ Een indicatie of er tijdens het verdunnen/mestuitrijden een storing is opgetreden

- $\quad$ Data waaruit blijkt dat er een voldoende mate van verdunning plaatsvindt

7.4 De mestverdunning/datalog/GPS apparatuur beschikt over een voorziening, waarmee databerichten behouden blijven indien er een storing optreedt in de mobiele datacommunicatie én waarmee de berichten alsnog worden verstuurd zodra de storing is opgeheven.

$8 \quad$ Signalering van storing

8.1 De mestverdunning/datalog/GPS apparatuur beschikt over een voorziening waarmee zichtbaar wordt gemaakt of elke te onderscheiden functies - en de onderlinge samenhang - van de mestverdunning/datalog/GPS apparatuur en de satellietvolgapparatuur correct functioneert. Het gaat hierbij om de functies:

- Vaststellen / monitoren voldoende mate van verdunning

- Vaststellen / monitoren niet verdunnen met gier

- Dataloggen (locatie, tijd, bovenstaande monitorgegevens)

- Versturen van gegevens

8.2 De mestverdunning/datalog/GPS apparatuur beschikt over een voorziening waarmee in het databericht automatisch wordt aangegeven of er gedurende het verdunnen/mestuitrijden de in 8.1 genoemde functies niet correct functioneren.

$9 \quad$ Kalibreren van sensoren 
9.1 De sensoren worden minimaal eens per jaar gekalibreerd door de eigenaar van de mestverdunning/datalog/GPS apparatuur.

9.2 Bewijslast voor de jaarlijkse kalibratie ligt bij de eigenaar van de mestverdunning/datalog/GPS apparatuur. 


\title{
Bijlage 6 Elektrische geleidbaarheid van rundveemest
}

\begin{abstract}
Introductie
In het voor- en najaar van 2018 zijn op verschillende bedrijven in totaal $12+17=29$ monsters mest verzameld uit mestkelders tijdens het vullen van de mesttank. De mest werd voordat het monster genomen werd zo goed als mogelijk gemengd. De mest werd geanalyseerd op gehalte totaal- $\mathrm{N}$, ammonium- $N$, totaal-P, Kalium, droge stof en as. Tevens werd de elektrische geleidbaarheid (EC) gemeten in $\mathrm{mS} / \mathrm{cm}$ van de onverdunde mest $(1: 0)$ en de verdunningen drie delen mest/één deel water $(3: 1)$, twee delen mest/één deel water $(2: 1)$ en één deel mest/één deel water $(1: 1)$ direct nadat verdunning plaatsvond.

Het doel van het onderzoek was om een kritische EC waarde te bepalen waaronder we er zeker van kunnen zijn dat mest minimaal 2: 1 verdund is met voldoende onderscheidend vermogen om 2:1 verdunde mest niet ten onrechte als te weinig verdunde mest aan te merken.
\end{abstract}

\section{Analyse Mest}

\section{Samenstelling}

Met ANOVA is onderzocht of de samenstelling van de mest voor een vijftal variabelen in het voorjaar en najaar van elkaar verschilt. Daarnaast is onderzocht of de residuele varianties in het voor- en najaar van elkaar afwijken (Levene test) en is een toets op normaliteit (Shapiro-Wilk test) toegepast

Tabel 1 Samenstelling mest.

\begin{tabular}{lllllll} 
& totaal-N & ammonium- $N$ & totaal-P & Kalium & droge stof & as \\
Najaar & 4.39 & 2.11 & 0.53 & 5.16 & 89.6 & 24.6 \\
\hline voorjaar & 4.42 & 2.16 & 0.60 & 4.48 & 87.3 & 24.0 \\
\hline p-waarde & 0.91 & 0.70 & 0.05 & 0.01 & 0.65 & 0.82 \\
\hline gemiddeld & 4.40 & 2.13 & 0.56 & 4.88 & 88.6 & 24.4 \\
\hline Sed & 0.23 & 0.13 & 0.03 & 0.22 & 4.91 & 2.85 \\
\hline
\end{tabular}

Conclusie: Voor Kalium wordt een significant verschil gevonden tussen het voor- en najaar. Voor de overige variabelen wordt niet aangetoond dat de samenstelling in het voor- en najaar van elkaar verschilt. In alle gevallen worden de aannames voor het uitvoeren van een geldige variantie analyse niet verworpen met uitzondering voor variabele as, $\mathrm{p}<0.05$ : de aanname van normaliteit wordt verworpen.

\section{EC waarde}

Met ANOVA is onderzocht of de elektrische geleidbaarheid van de mest voor de verdunningen onverdund, $1: 0,3: 1,2: 1$ en $1: 1$ in het voorjaar en najaar van elkaar verschilt:

Tabel 2 EC waarde mest bij voorjaars-en bij najaarsmonsters en p-waarde, gemiddelde, standaard fout voor verschillen (sed) en standaard afwijking (sd).

\begin{tabular}{lllll} 
& $1: 0$ & $3: 1$ & $2: 1$ & $1: 1$ \\
Najaar & 21.59 & 19.10 & 17.66 & 14.25 \\
\hline Voorjaar & 20.62 & 18.06 & 16.74 & 13.56 \\
\hline p-waarde & 0.26 & 0.13 & 0.15 & 0.19 \\
\hline gemiddeld & 21.19 & 18.67 & 17.28 & 13.97 \\
\hline Sed & 0.85 & 0.67 & 0.62 & 0.52 \\
\hline Sd & 2.25 & 1.77 & 1.66 & 1.37 \\
\hline
\end{tabular}


Conclusie: Voor de toegepaste verdunningen wordt niet aangetoond dat de EC-waarden van de $\mathrm{t}$ voorjaars monsters verschillen van de najaars monsters. In alle gevallen worden de aannames voor het uitvoeren van een correcte variantie analyse niet verworpen. (sed: standaard fout voor verschillen; sd: standaard afwijking).

\section{Berekening kritische EC-waarde}

Voor de drie verdunningen, aangeduid als 1:0, 2:1 en 1:0, staan in tabel 3 de gemiddelde EC waarde, variantie en standaarddeviatie.

Tabel 3 gemiddelde, variantie en standaard deviatie.

\begin{tabular}{llll} 
verdunning & gemiddelde $(\mathrm{ms} / \mathrm{cm})$ & Variantie $\left(\mathrm{sd}^{2}\right)$ & 2.26 \\
\hline $1: 0$ & 21.19 & 5.11 & 1.69 \\
\hline $2: 1$ & 17.28 & 2.86 & 1.39 \\
\hline $1: 1$ & 13.97 & 1.94 & standaard dev $(\mathrm{sd})$ \\
\hline
\end{tabular}

Er wordt gekeken naar de op dit moment in praktijk gebruikelijke verdunning $2: 1$. Bij deze verdunning is het gemiddelde $17.28 \mathrm{mS} / \mathrm{cm}$ en voor $\mathrm{n}=29$ waarnemingen wordt de standaardfout van het gemiddelde berekend als se $=1.69 / \sqrt{ } \mathrm{n}=1.69 / \sqrt{ } 29=0.314$.

In onderstaande figuur zijn voor de verdunningen 1:0, 2:1 en $1: 1$ de verdelingen rond het gemiddelde weergegeven. Gemakshalve is voor elk gemiddelde dezelfde standaard fout genomen.

Een eenzijdige toets met $a=0.05$ levert als linker kritieke waarde op $17.28-1.645 * 0.314=16.76$ $\mathrm{mS} / \mathrm{cm}$.

De oranje lijn in de figuur geeft de linker kritieke waarde voor het EC gehalte van de 2:1 verdunde mest (blauwe curve). Het oppervlakte van de curve links van de oranje lijn is gelijk aan $5 \%$.

De $1: 1$ verdunde mest ligt in zijn geheel (100\%) onder de EC waarde $16.76 \mathrm{mS} / \mathrm{cm}$

\section{verdunningen: $16.76(\mathrm{mS} / \mathrm{cm})$}

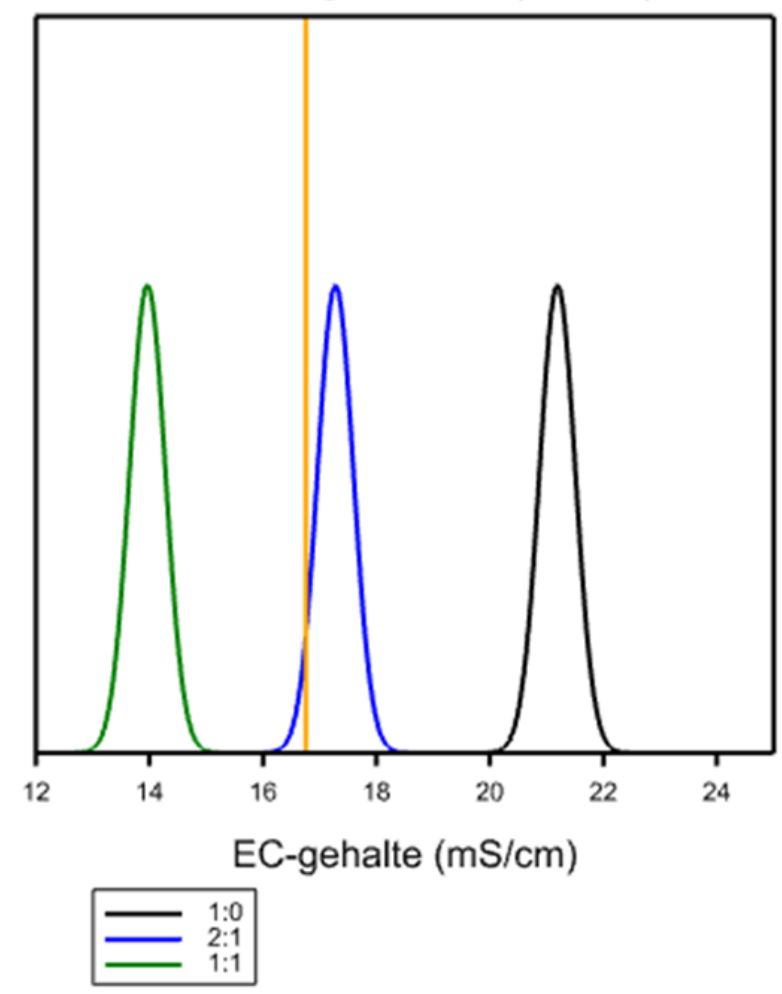

Figuur 1 Verdelingen rond het gemiddelde voor verdunningen. 
Om er zeker van te zijn dat de mest voldoende verdund, 2:1 overeenkomstig de praktijk, dan moet het EC gehalte lager zijn dan $16.76 \mathrm{mS} / \mathrm{cm}$. Anders geformuleerd, met een kans van 5\% op een verkeerde beslissing (fout van de 1ste soort) willen we mest verdunnen, zodanig dat de verdunning minimaal gelijk is of zelfs nog meer verdund dan wat in de praktijk gebruikelijk is (2:1). Deze verdunning komt dan overeen met een EC gehalte lager dan $16.76 \mathrm{mS} / \mathrm{cm}$.

In Figuur 2 wordt het onderscheidingsvermogen of de power weergegeven. De power is de kans dat wanneer er voldoende verdund is (dus meer dan 1 deel water op 2 delen mest, overeenkomend met een EC waarde kleiner dan $16.67 \mathrm{mS} / \mathrm{cm}$ ) dit ook inderdaad gevonden wordt.

Als in een verdunningsexperiment exact een EC gehalte van $16.76 \mathrm{mS} / \mathrm{cm}$ wordt gevonden is de power $50 \%$. Als er meer wordt verdund (en het EC gehalte is veel lager dan $16.76 \mathrm{mS} / \mathrm{cm}$ ) neemt de power toe (en de kans dat ten onrechte geconcludeerd wordt dat de verdunning onvoldoende is af = fout van de 2 e soort). In de figuur wordt de waarde bij een kans van $50 \%$ aangeven met een verticale rode lijn. De power is $5 \%$ wanneer een verdunningsexperiment een waarde van $17.28 \mathrm{mS} / \mathrm{cm}$ oplevert (merk op dat dit de waarde is van verdunning 2:1).

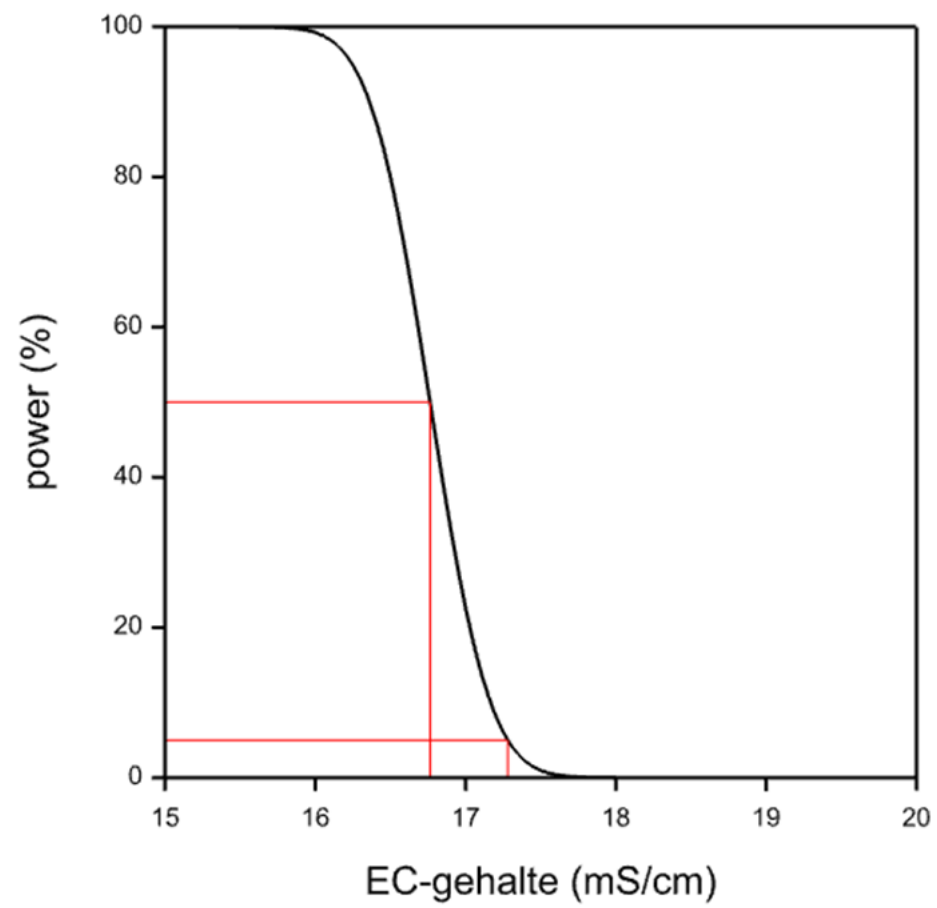

Figuur 2 Power.

Naarmate de kritische EC waarde lager wordt (opschuift naar links) neemt de power toe.

\begin{tabular}{ll} 
EC gehalte $\mathrm{ms} / \mathrm{cm}$ & Power $(\%)$ \\
16.00 & 99.25 \\
\hline 16.10 & 98.28 \\
\hline 16.20 & 96.37 \\
\hline 16.30 & 93.02 \\
\hline 16.40 & 87.67 \\
\hline 16.50 & 79.95 \\
\hline 16.60 & 69.89 \\
\hline 16.70 & 58.02 \\
\hline 16.76 & 50.00 \\
\hline
\end{tabular}

Bij een betrouwbaarheid (Power) van minimaal $85 \%$ is de EC gehalte $16.40 \mathrm{mS} / \mathrm{cm}$. 
Tot slot is een regressie uitgevoerd van het EC gehalte van de vier verdunningen op de variabelen die de samenstelling van de mest bepalen:

Verdunning 1:0 (onverdund)

All Possible Subsets Regression

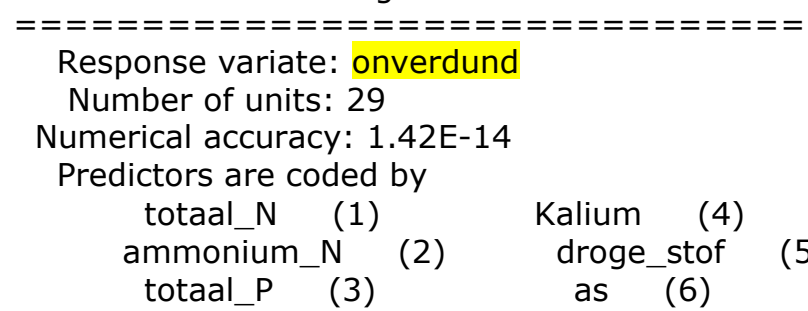

Best subsets with 1 predictor (2 parameters)
R2 Adj Cp MnTol
(1)
(2)
(3)
(4) (5)
(6)
$\begin{array}{llll}27.08 & 24.38 & 38.13 & 1.000\end{array}$
$\begin{array}{llll}25.10 & 22.33 \quad 39.85 & 1.000\end{array}$
3.17

Best subsets with 2 predictors ( 3 parameters)

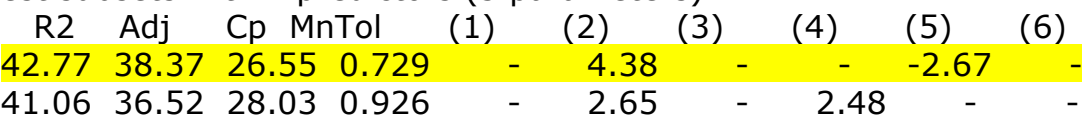

\section{Verdunning 3:1}

All Possible Subsets Regression

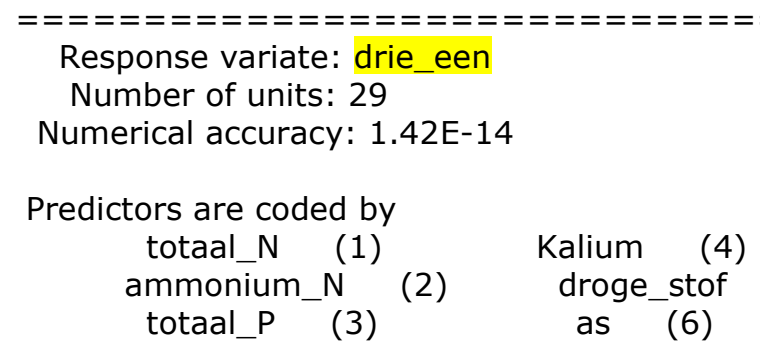

Best subsets with 1 predictor ( 2 parameters)
R2 Adj Cp MnTol
(1)
(2) (3)
(4)
(5) (6)
$45.38 \quad 43.36 \quad 36.04 \quad 1.000$
$\begin{array}{llll}42.85 & 40.73 \quad 38.88 & 1.000\end{array}$

$-$
4.74

Best subsets with 2 predictors ( 3 parameters)

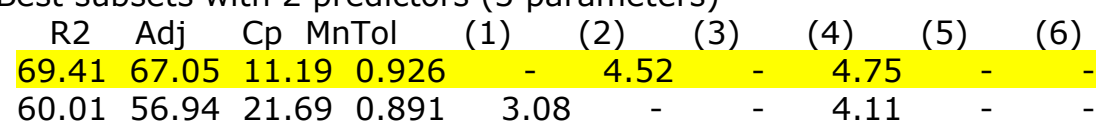

Verdunning 2:1

All Possible Subsets Regression

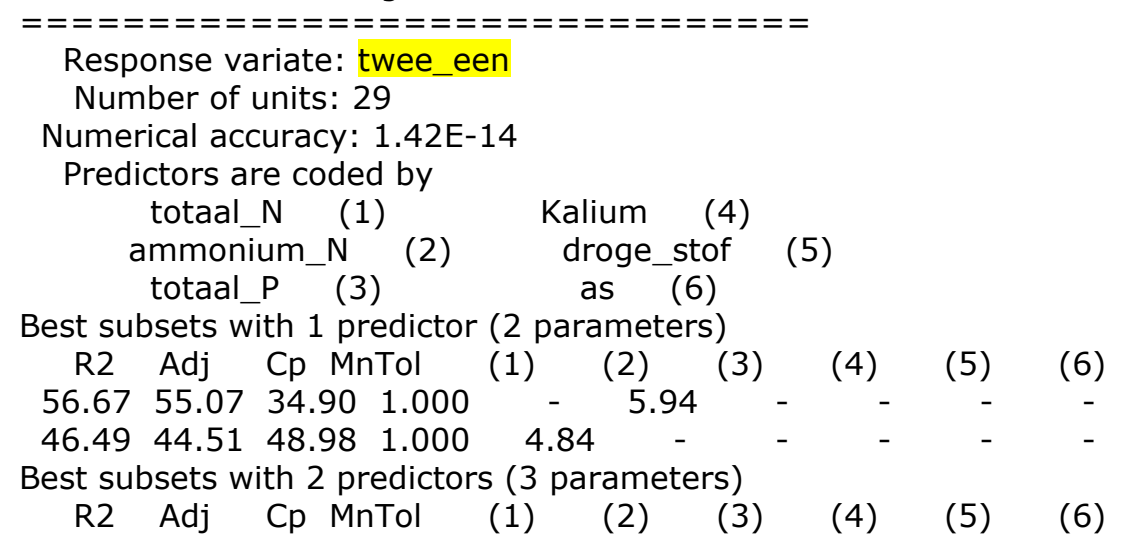




$\begin{array}{llllllllll}75.00 & 73.08 & 11.55 & 0.926 & - & 6.20 & - & 4.37 & - & - \\ 63.69 & 60.90 & 27.19 & 0.891 & 4.29 & - & - & 3.51 & - & -\end{array}$

Verdunning 1:1

All Possible Subsets Regression

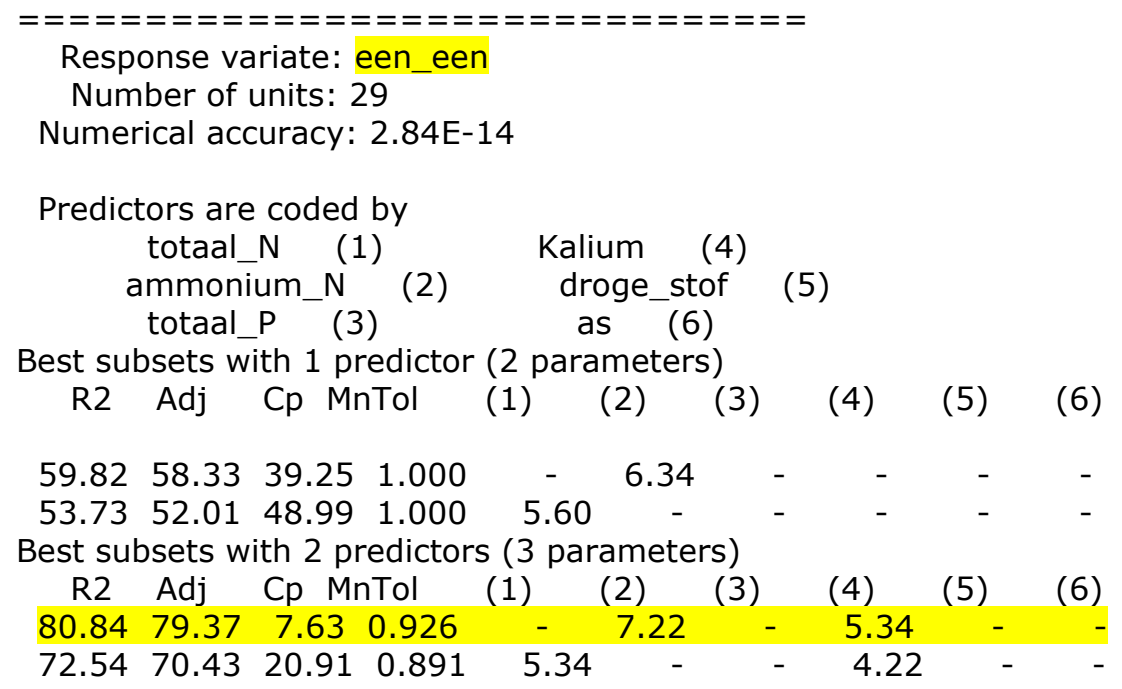

Uitleg onverdunde mest 1:0

De twee beste modellen met 1 verklarende variabele bevatten ammonium_N en Kalium. Het percentage verklaarde variantie is resp. 27 en $25 \%$. De twee beste modellen met twee verklarende variabelen bevatten 1) ammonium_N en droge_stof en 2) ammonium_N en Kalium met percentage verklaarde variantie resp. 43 en $41 \%$..

Merk op dat het percentage verklaarde variantie voor de echte verdunningen toeneemt, voor de verdunning $1: 1$ is het hoogste percentage $81 \%$ voor een model met als verklarende variabelen ammonium_N en Kalium. 

